\title{
Varieties of entrepreneurship: exploring the institutional foundations of different entrepreneurship types through 'Varieties-of-Capitalism' arguments
}

\author{
Selin Dilli • Niklas Elert • Andrea M. Herrmann
}

Accepted: 30 November 2017 /Published online: 29 March 2018

(C) The Author(s) 2018

\begin{abstract}
While entrepreneurship researchers agree that institutions 'matter' for entrepreneurship, they also have a rather encompassing understanding of institutions as almost any external factor that influences entrepreneurship. Ultimately, this literature thus comes up with a long list of institutional factors that may explain entrepreneurial differences between countries. But which institutions are most influential? How do these institutions relate to different types of entrepreneurship? And to what extent are institutions complementary to each other in the way they sustain different entrepreneurship types? The literature on 'Varieties-of-Capitalism' (VoC) offers a parsimonious theoretical framework to address these questions. Based on the $\mathrm{VoC}$ literature, we theoretically derive a consistent set of institutional indicators that can explain differences in entrepreneurship types between countries. Based on principal component and cluster analyses, we illustrate how 21 Western developed economies cluster around four distinct institutional settings. Furthermore, we use simple OLS regressions to show how these institutional constellations are related to
\end{abstract}

S. Dilli $(\bowtie) \cdot$ A. M. Herrmann

Utrecht University, Utrecht, Netherlands

e-mail: S.Dilli@uu.nl

A. M. Herrmann

e-mail: A.M.Herrmann@uu.nl

N. Elert

Research Institute of Industrial Economics (IFN), Stockholm, Sweden

e-mail: Niklas.Elert@ifn.se different types of entrepreneurship. We conclude that four different 'Varieties of Entrepreneurship' can be identified across the Western world. The main implication of our findings is that a 'perfect' institutional constellation, equally facilitating different types of entrepreneurship, does not exist. Policy-makers seeking to stimulate entrepreneurship are thus faced with the trade-off of targeting policy reforms to that entrepreneurship type they intend to promote - at the expense of other types of entrepreneurship and the broader societal consequences such reforms will have.

Keywords Entrepreneurship · Entrepreneurial ecosystems · Varieties-of-Capitalism · Institutional complementarities

JEL classification $\mathrm{L} 26 \cdot \mathrm{L} 5 \cdot \mathrm{M} 13 \cdot \mathrm{O} 31 \cdot \mathrm{P} 14$

\section{Introduction}

Different varieties of entrepreneurship exist. But what do these different types of entrepreneurship look like? And why do they emerge? The entrepreneurship literature started to explore these questions in the early 1990s, stating that the manner in which a society's institutions structure economic payoffs influences the nature of entrepreneurial efforts and activities (Baumol 1990; Murphy et al. 1990; Sobel 2008; Calcagno and Sobel 2014). Over the years, a consensus has emerged that formal and informal institutions incentivize individual behaviour (North 1990), thereby influencing the extent 
and character of an economy's entrepreneurial activity (Acs et al. 2008; Stenholm et al. 2013; Urbano and Alvarez 2014). Formal institutions that have been identified as particularly important for entrepreneurship include the protection of private property, tax codes, social insurance systems, employment protection legislation, competition policy, trade policies, capital market regulation, contract enforcement, as well as law and order (Hall and Jones 1999; Henrekson and Johansson 2009; Bjørnskov and Foss 2013). Informal institutions influencing entrepreneurship encompass social capital, trust, individualism, power distance, and uncertainty avoidance (Hechavarria and Reynolds 2009; Taylor and Wilson 2012). In short, the current literature suggests that entrepreneurship takes different forms between countries or regions, inter alia, because of institutional differences (see, e.g., Case and Harris 2012; WEF 2013; Stam 2014).

Accordingly, the literature on institutions and entrepreneurship thus comes up with an eclectic list of institutional factors that may explain entrepreneurial differences between countries. A clear-cut concept of institutions is missing, as well as a parsimonious understanding of the core institutions shaping different types of entrepreneurship. Such an understanding is needed, however, for both theoretical and practical reasons: A parsimonious theoretical framework would enable future research to move away from an eclectic towards a more focused investigation of how specific core institutions influence entrepreneurship. From a practical perspective, such insights are highly useful for all those policy-makers who aim to foster entrepreneurship in general, and distinct types of entrepreneurship in particular.

Consequently, we ask here: How do institutions that are relevant for entrepreneurship form distinct complementary constellations? And which forms of entrepreneurship are facilitated by these institutional constellations?

To address these questions, we use the Varieties-ofCapitalism (VoC) literature to develop a theoretical framework about how distinct national institutions and their complementarities facilitate the development of different types of entrepreneurship. Ever since the publication of its core oeuvre by Hall and Soskice (2001), the VoC literature has become one of the most influential explanations of how national institutions lead to differences in economic behaviour across countries. In line with this literature, we define institutions as the written or verbally agreed 'rules of the game' that lead to systematic behaviour on the part of actors (individuals and organisations) (see Streeck and Thelen 2005), in this case entrepreneurs and their ventures.

In a nutshell, the VoC literature illustrates how a distinct and highly parsimonious set of institutions governing the exchange between companies and their national labour markets, financial markets, and research \& development (R\&D) collaborations lead to different 'models of capitalism', translating into different innovation, technology, and production outcomes across economies. These 'varieties of capitalism' are considered to be particularly stable because of the complementarities of their underpinning institutions. Institutions are complementary "if the presence (or efficiency) of one [institution] increases the returns from (or efficiency) of the other" (Hall and Soskice 2001: 17).

While the VoC arguments are meant to apply to all sorts of companies active in the manufacturing sector, it is interesting to note that the VoC literature has developed through studies of established firms and the institutions channelling their behaviour. Institutional impacts on establishing entrepreneurial ventures are less researched. By illustrating how distinct institutional constellations are linked to specific types of entrepreneurship, our study also contributes to closing this gap.

We focus our analyses on the United States (US) and those 20 European economies which have been studied most intensely in the $\mathrm{VoC}$ literature. Based on factor, cluster, and regression analyses of institutional indicators that are particularly relevant for entrepreneurship, we show (1) how a core set of institutions governing the exchange between entrepreneurial ventures and their shareholders, workforces, and R\&D partners differ systematically and in a parsimonious way between countries and (2) how these institutional constellations facilitate the development of different types of entrepreneurship.

To illustrate these points, our paper is structured as follows: Section 2 draws on the VoC and entrepreneurship literatures in order to develop a consistent theoretical framework. We use the framework to develop hypotheses about which types of institutions chiefly influence entrepreneurship. In Section 3, we describe the data and methods we use, while we present the results in Section 4. Finally, Section 5 concludes by discussing the results obtained. 


\section{Theory}

Across the entrepreneurship literature, agreement is broad that distinct types of entrepreneurship occur with different frequencies between countries. In order to explain how such differences are caused by distinct institutional constellations, we conceptualise entrepreneurship in line with Henrekson and Stenkula's (Henrekson and Stenkula 2016: 71; closely related to Wennekers and Thurik 1999) as:

"the ability and willingness of individuals, both independently and within organisations,

- to discover and create new economic opportunities;

- to introduce their ideas in the market under uncertainty, making decisions regarding the localization, product design, use of resources and reward systems; and

- to create value, which often, though not always, means that the entrepreneur aims to expand the firm to its full potential."

More concretely, we think of entrepreneurship as a continuum which ranges from Schumpeterian entrepreneurship on one end to its non-Schumpeterian counterpart on the other. While Schumpeterian entrepreneurship is characterised as risk-loving, based on radical innovations, and aiming for high corporate growth, non-Schumpeterian entrepreneurship is risk-avoiding and based on imitation, without aiming for corporate growth.

This distinction between Schumpeterian and nonSchumpeterian entrepreneurship can be made at different moments of entrepreneurial activity: First, before the start of a new venture. At that stage, an important distinction is whether the potential entrepreneur perceives good business opportunities or rather is faced with the necessity to earn his or her living (Coad 2009:131; Vivarelli 2013: 1476). Importantly, such perceptions of entrepreneurial opportunities or necessities do not automatically translate into the starting-up of an entrepreneurial venture.

Second, at the moment of venture creation, entrepreneurship differs considerably in the extent of its innovativeness. While the technology-intensity of some (few) ventures is highly innovative in a Schumpeterian sense, thus having the potential for creative destruction (Vivarelli 2013: 1458), many new ventures are less technology intense or are mere imitators copying the business ideas of others. Interestingly, the propensity for innovation generally emerges as a driver of firm growth (Freel 2000; Coad and Rao 2008; Altindag et al. 2011; Corsino and Gabriele 2011), and several studies find a positive relationship between innovation and performance (Vivarelli and Audretsch 1998; Colombo and Grilli 2005).

Consequently and finally, the growth aspirations of founders during the early life of a new venture are an additional important characteristic that distinguishes Schumpeterian from non-Schumpeterian entrepreneurship. While Schumpeterian 'high impact entrepreneurs' exhibit high growth aspirations and a propensity for rapid growth (Acs 2008), "most small businesses are best described as permanently small" and thus nonSchumpeterian in their growth aspirations (Henrekson and Sanadaji 2014:1760).

To identify the core of institutions that are most influential to any kind of business activity, the $\mathrm{VoC}$ literature draws on the fundamental insights of economic theory (Williamson 1985; Milgrom and Roberts 1992; Teece and Pisano 1998) and the resourcedependence view (Pfeffer and Salancik 1978), arguing that three types of resources are key for any business to operate: finance, labour, and know-how. These resources are considered essential, because companies can only secure them after solving a collective action problem with external economic actors, namely financiers, workforces, and R\&D partners. Consequently, institutions that channel the interaction between firms and their financiers, workforces, and R\&D partners are considered to be the most economically impactful ones (i.e. they offer comparative advantages). Accordingly, the VoC literature explains how finance-related institutions, labour-market as well as education-related institutions, and institutions governing inter-organisational collaborations take different shapes between countries, thereby leading to different institutional settings on the one hand and different types of corporate behaviour on the other.

In its original form, the $\mathrm{VoC}$ literature identified just two different institutional settings, termed Liberal Market Economies (LMEs) and Coordinated Market Economies (CMEs). In LMEs, such as the US or the UK, competition prevails as labour and financial markets are deregulated, so that shareholder capital is available to firms in the short run, while labour is mobile. This deregulated institutional environment leads firms to engage with their business partners in a highly competitive 
way, thereby facilitating radical innovations. In CMEs, exemplified by Germany, economic actors often engage with each other on the basis of nonmarket relationships. The institutions regulating financial and labour markets tie shareholders as well as workforces to 'their' firm. This, in turn, leads firms to cooperate closely with their financiers and employees, which makes the institutional environment conducive to incremental (technological) innovation (Hall and Soskice 2001).

The dichotomous distinction between CMEs and LMEs initiated a debate about the heterogeneity of CMEs and LMEs, as well as about additional country groups (e.g., Amable 2003; Hancké et al. 2007; Schneider and Paunescu 2012). Accordingly, researchers pointed out that more varieties of capitalism can be observed than CMEs and LMEs. Among the most researched economies, at least two more institutional models have been recognised, namely Mediterranean Market Economies (MMEs) and Eastern European Market Economies (EMEs).

Due to their recent histories of extensive state intervention, firms in MMEs have built specific capabilities of non-market coordination in the sphere of corporate finance, whereby they are characterised by slightly more liberal arrangements in the sphere of labour relations (Hall and Soskice 2001: 21). Overall, MMEs provide moderate levels of social protection with high investments into poverty alleviation and pensions. External shareholders are not well protected, and venture capital from national investors is hardly available. Similarly, national expenditure for education is limited. This firms in MMEs a comparative advantage in low-cost production-with the exception of some niche markets, for example furniture or fashion, where Italian firms compete on incremental innovations and design (Molina and Rhodes 2007).

EMEs have a comparative advantage in the assembly and production of relatively complex and durable consumer goods. These comparative advantages are based on institutional complementarities which combine low labour costs and a skilled population with substantial knowledge of medium-level technologies. Contrary to CMEs, employers in EMEs are unwilling to bear the additional costs of on-the-job training for inexperienced young workers. Regarding financial markets, foreign direct investment is by far the most important source of capital. Domestic bank lending, the second most important source of finance, is dominated by transnational companies (Hancké et al. 2007; Nölke and Vliegenthart 2009).

Importantly, the $\mathrm{VoC}$ reasoning about how institutions governing the exchange between established firms and their workforces, financiers, and R\&D partners translate into different forms of economic activity can well be applied to entrepreneurial ventures. To begin with finance-related institutions, the VoC literature points out how institutions differ in how they address the principal-agent problem related to the provision of shareholder capital (see Hall and Soskice 2001; Vitols 2001). In short, to be willing to provide funding, shareholders need to be assured that their investment is used in the most efficient way by the corporate management.

In so-called outsider corporate governance systems, most pronounced in LMEs, shareholders have hardly any say in how (their) funds are invested, so that managers have unilateral power to take major strategic and financial decisions. Consequently, shareholders monitor the soundness of managerial decisions chiefly through the development of equity prices on the stock market, which leads corporate managers to maximise return on investment by engaging in high-risk, radical innovation projects (idem).

The opposite applies to so-called insider corporate governance systems, most pronounced in CMEs, which grant shareholders the right to elect their representatives onto a supervisory board with a say in all major strategic investment decisions. This gives shareholders both a say and insights into how their funds are used and, in turn, makes them more patient towards maximising returns on investment in the short run-given in particular that the shareholders on corporate supervisory boards are also major stakeholders of the company, such as suppliers or 'house banks'. Consequently, the board members often prefer projects based on incremental innovations, as the latter guarantee lower, but more stable and predictable returns over a longer period of time (idem).

Translating these insights to the development of different forms of entrepreneurship, one can expect that outsider corporate governance institutions (typical for LMEs) 'push' founders to engage in more Schumpeterian forms of entrepreneurship, whereas founders in insider corporate governance systems find it easier to engage in less Schumpeterian forms of entrepreneurship.

Importantly, though, these $\mathrm{VoC}$ arguments chiefly apply to incumbent firms or fast-growing start-ups which are publicly listed or have a size or legal form 
that requires a supervisory board. Given that most new ventures are rather small, not listed on the stock market, and have a legal form that does not require a supervisory board, the entrepreneurship literature points out that additional finance-related institutions influence the likelihood and conditions with which shareholders provide funds to a start-up company.

Another important institutional difference exists with regard to the minimum capital requirements (MCRs). Countries differ substantially in their requirements concerning the minimum amount of capital that founders need to place into their venture at its inception. This is particularly true for limited liability companies. The lower the amount of capital required, the less severe are the principal-agent conflicts that might occur between founders and managers at a later stage, and the easier it is for founders to open a venture. Given that Schumpeterian ventures are particularly prone to failure, their shareholders have an increased interest in not being personally liable. We therefore expect that countries with no or low minimum capital requirements facilitate more Schumpeterian forms of entrepreneurship than countries with high capital requirements.

Major institutional differences also exist regarding the extent to which national institutions facilitate access to venture capital. To begin with, pension laws foresee different ways in which the funds destined for future retirees are administered. In many Continental European economies (often CMEs), companies are required to take provisions and thus administer huge amounts for future pensions, whereas in most Anglo-Saxon economies (LMEs), individuals need to provide for their pensions. Notably, companies in charge of their employees' future pensions tend to be more conservative in their investment strategies than individuals. They often choose less risky investment options, hardly investing in venture capital funds. Consequently, the availability of venture capital funds is systematically more limited in CMEs than in the LMEs (Bottazzi and Da Rin 2002; Da Rin et al. 2006).

In addition to national pension systems, tax regulations also lead to national differences in the availability of venture capital (VC). Accordingly, the modern VC industry in the US could not evolve until the tax system was changed in several key aspects (Misher 1984; Fenn et al. 1995): In the 1970s and 1980s, US policy-makers implemented sharp tax cuts in capital gains with legislation allowing pension funds to invest in high-risk securities issued by small and new firms as well as VC funds (Gompers and Lerner 1999; cf. Keuschnigg and Nielsen 2004). Additionally, effective tax treatments of options contracts were needed to enable VC firms to appropriately incentivize founders to foster innovative firms (Henrekson and Rosenberg 2001; Henrekson and Sanadaji 2014). Taken together, we expect that institutions facilitating the availability of venture capital stimulate the development of Schumpeterian entrepreneurial ventures.

Finally, the propensity of shareholders to invest in start-ups depends not only on their rights in case of venture success but also on shareholder rights in case of disagreement with the management and venture failure. Entrepreneurial ventures are often not successful in generating sustainable profits: only about $50 \%$ of newly founded firms survive for more than 5 years (Geroski 1995; OECD 2003; Bartelsman et al. 2005; Delmar and Wennberg 2010). In case of failure, shareholders' possibilities to disinvest depend importantly on the rights of creditors to recover their investments which, in turn, are determined by national institutions. The more easily creditors can recover the funds provided to entrepreneurial ventures, the more likely it is that ventures will be sold piecemeal instead of emerging from the proceedings as a going concern; the more constrained shareholders are in their disinvestment decisions, the more reluctant they are to invest in ventures in the first place.

The above reasoning leads us to the first proposition and hypothesis.

Proposition 1:

Finance-related institutions supporting entrepreneurship differ between countries in the extent to which they affect shareholders in their investment options.

Hypothesis 1:

The less finance-related institutions constrain shareholders, the more Schumpeterian are the types of entrepreneurship that develop in the respective countries.

With regard to labour, the VoC literature highlights how national labour-market institutions, as well as the institutions at the basis of national education systems, address this free-riding problem. To begin with labourmarket institutions regulating permanent employment, rigid institutions (typical for CMEs) - such as wage- 
bargaining centralisation, powerful works councils with authority over layoffs, long notice periods, and a pronounced use of competition clauses-tie employees to the same firm for a long period of time. Consequently, both employers and employees are assured that their investment in sophisticated, firm-specific skills will pay off (Hall and Soskice 2001: 25). Employees in rigid labour markets therefore often have in-depth corporate knowledge and long-standing relationships with supplying companies. Such firm-specific skills enable them to autonomously propose and develop improvements that translate into incremental innovations and high-quality products (see Herrmann and Peine 2011) at the basis of stable yet slow-growth forms of entrepreneurship.

The opposite applies to flexible labour-market institutions regulating dependent employment (typical for LMEs), such as wage-bargaining decentralisation, weak works councils, short notice periods, and a limited use of competition clauses. Faced with the possibility of hire-and-fire at short notice, employees acquire general skills that are useful for, and thus adequately rewarded by, all firms needing a certain business function. General skills facilitate radical innovations, and new business ideas as employees are particularly imaginative and flexible in adapting to new corporate environments because of their frequent job changes (see Herrmann and Peine 2011). We therefore expect that flexible labourmarket institutions regulating permanent employment will facilitate the development of Schumpeterian entrepreneurial ventures.

Importantly, these arguments from the VoC literature apply to workforces with permanent employment contracts. However, the entrepreneurship literature highlights that entrepreneurial ventures often employ workforces on a temporary basis (in the form of trainees, temp agency workers, or employees with fixed-term contracts) in order to be able to quickly adjust their human resources' needs to the rapidly changing business development. Yet, national institutions also differ substantially in the extent to which they allow for temporary employment. While flexible labour-market institutions allow for systematic and repeated temporary work, rigid labour-market institutions require temporary work to be changed into permanent employment under specific circumstances. Rigid labour-market institutions thus tie employees to the same firm, whereas flexible labour market institutions have the opposite effect (Golpe et al. 2008; Román et al. 2011). We therefore expect that flexible labour-market institutions regulating temporary employment will facilitate the development of Schumpeterian entrepreneurial ventures.

In order to facilitate entrepreneurship in general, and Schumpeterian ventures in particular, many countries have initiated labour market programmes providing social spending for start-up initiatives. Given that start-up incentives increase the attractiveness of entrepreneurship as a source of income, such programmes influence the career choices of workforces - partly offsetting the impact of labour-market flexibility or rigidity on their career trajectories (Hessels et al. 2007). We expect that the more developed labour market programmes offering start-up incentives are, the more Schumpeterian entrepreneurial ventures will develop within a country.

The above reasoning leads us to the second proposition and hypothesis.

Proposition 2:

Labour-market institutions supporting entrepreneurship differ between countries in the extent to which they facilitate the short-term engagement of workforces in entrepreneurial ventures.

Hypothesis 2:

The more labour-market institutions facilitate the short-term engagement of workforces in entrepreneurial ventures, the more Schumpeterian are the types of entrepreneurship that develop in the respective countries.

Workforces acquire skill profiles supporting different types of entrepreneurship not only after entering the labour market; they already begin acquiring them during their education and training period. Institutions governing a country's education and training systems differ in the extent to which they endow future workforces with the multi-tasking skills needed for entrepreneurship in general and for Schumpeterian entrepreneurship in particular.

The VoC literature illustrates how rigid labourmarket institutions (typical for CMEs) are often complementary to sophisticated national vocational training programmes that train future workforces in firm-specific skills - often in close collaboration with companies needing these skills. Tertiary education programmes, on the other hand, teach general skills that can be used across different companies (Hall and Soskice 2001; 
Schneider and Paunescu 2012). In line with the VoC reasoning, we expect that countries with less welldeveloped vocational training systems will lead more workforces to engage in tertiary education and thus, to be better equipped with general skills, facilitating Schumpeterian entrepreneurial ventures.

The entrepreneurship literature also highlights the importance of scientific knowledge for the development of entrepreneurial ventures in general, and Schumpeterian forms of entrepreneurship in particular. Given that Schumpeterian entrepreneurial ventures come up with radically new innovations, they are typically based on technological inventions developed by scientifically oriented workforces. Yet, workforces with scientific skills are not only educated within a country, they are also hired from abroad (Herrmann 2008; Herrmann and Peine 2011). The academic systems of the US, the UK, and the Netherlands are examples of countries that not only offer sophisticated scientific training but also attract high numbers of immigrant scientists. We therefore expect that institutions facilitating the development and attraction of scientific knowledge will facilitate the development of Schumpeterian entrepreneurial ventures.

Furthermore, knowledge-intensive innovation is frequently considered to be the outcome of R\&D activities. In addition to the scientific knowledge generated by the private sector, entrepreneurial ventures may therefore also acquire the necessary scientific knowledge by participating in or benefitting from public $R \& D$ programmes that lead to new commercial opportunities. Yet, the extent to which such programmes are set up by policy-makers differs substantially between countries. We therefore expect that more national R\&D activities will facilitate the development of more Schumpeterian forms of entrepreneurship.

The above reasoning leads us to the third proposition and hypothesis.

\section{Proposition 3:}

Education- and training-related institutions supporting entrepreneurship differ between countries in the extent to which they facilitate the development of scientific knowledge.

Hypothesis 3:

The more education- and training-related institutions facilitate the development of scientific knowledge, the more Schumpeterian are the types of entrepreneurship that emerge in the respective countries.

Firms often engage in R\&D collaborations with other organisations - such as suppliers, universities, or research labs - in order to jointly develop the know-how needed for the new product or service development (Lundvall 1992; Tate 2001: 444-6). This is particularly true for small entrepreneurial ventures. The VoC literature illustrates the hold-up problem related to such interorganisational development of know-how. It arises whenever two or more parties seek to appropriate the intellectual property developed by their cooperation partner without having adequately contributed to the development of this know-how (see Rogerson 1992: 777; Klein 1996).

The VoC literature furthermore argues that institutions governing inter-firm collaborations influence the extent to which companies can protect themselves against the theft of intellectual property (IP), depending on the extent to which institutions facilitate the enforcement of $R \& D$ contracts between collaboration partners (Tate 2001; Teubner 2001). Two ways are identified: in countries with code-based ('Continental') law, typical for CMEs, hold-up is overcome by a fairly predictable outcome of lawsuits because of the clearly pre-defined conditions for IP theft to be present. The obligations laid out in R\&D contracts can thus be enforced in a straightforward manner. Given that this limits the risks of IP theft, firms in code-based law systems show a higher propensity to collaborate in $\mathrm{R} \& \mathrm{D}$ processes on a large scale which, in turn, facilitates incremental product improvements rather than radical innovations.

The opposite holds true for countries with a common-law tradition, typical for LMEs, where the case-by-case decisions of judges or lay juries make the outcome of lawsuits unpredictable. Consequently, firms often find it difficult to have the contractual obligations of their R\&D collaboration partners enforced by courts. This, in turn, discourages large-scale cooperation and stimulates fierce competition between potential collaboration partners, which is at the basis of radical innovation. We therefore expect that institutions hindering the straightforward enforceability of contracts between collaboration partners will facilitate Schumpeterian forms of entrepreneurship.

While the VoC arguments refer to situations in which well-functioning legal systems are in place, the 
entrepreneurship literature illustrates that unreliable legal systems prevent entrepreneurial ventures not only from engaging in R\&D collaborations but also from any form of radical or incremental innovation. Institutions prohibiting judicial independence, impartial courts, the protection of property rights, and the integrity of the legal system discourage firms in general-and Schumpeterian entrepreneurial ventures in particular-from being innovative, as they cannot protect their innovations from IP theft (Autio and Acs 2010; Stenholm et al. 2013). We therefore expect that institutions facilitating the reliability of legal systems will foster the development of Schumpeterian forms of entrepreneurship.

The above reasoning leads us to the fourth proposition and hypothesis.

\section{Proposition 4:}

Institutions governing inter-firm relations differ between countries in the extent to which they facilitate R\&D competition between companies.

\section{Hypothesis 4:}

The more institutions governing inter-firm relations offer reliable environments for R\&D competition, the more they facilitate the development of Schumpeterian entrepreneurship.

Having identified those institutions that are presumably most influential for entrepreneurship, the question arises as to how these institutions relate to each other. Again, the $\mathrm{VoC}$ literature offers advice by arguing that institutions are complementary, so that the presence of one increases the efficiency of the other (Hall and Soskice 2001: 17). Amable (2003: 6) offers a useful example: "Flexible labour markets may be more efficient when financial markets allow for a rapid mobilization of resources and creation of new businesses that in return sustain labour demand. Conversely, a more stable employment relationship may be more efficient when a specific pattern of monitoring is implemented in the context of a close relationship between a firm and a bank." Translating the idea of institutional complementarity to the development of different forms of entrepreneurship, we expect that

\section{Proposition 5:}

Distinct institutional families emerge more strongly when finance-related, labour-market, educational, and inter-firm institutions are considered jointly rather than separately.
Hypothesis 5:

Finance-related, labour-market, educational, and inter-firm institutions together facilitate different types of entrepreneurship more strongly than each institution does separately.

\section{Methodology}

To test these hypotheses, we conduct a two-step analysis. In the first step, we use factor and cluster analyses in order to assess whether - and, if so, how - the aforementioned finance-related, labour-market, education and training, and inter-firm institutions form distinct and complementary institutional constellations. In a second step, we then use ordinary least square regression analyses in order to assess how the institutional constellations identified support different types of entrepreneurship. Taken together, our analyses show that different varieties of entrepreneurship exist and illustrate what they look like.

\subsection{Case selection}

Our country sample is composed in line with the original VoC literature (Hall and Soskice 2001: 20) and its bestknown developments (Amable 2003; Hancké et al. 2007; Molina and Rhodes 2007; Schneider and Paunescu 2012). It focuses on the European economies as they have been studied most by the VoC contributors. In addition, we include the United States as a reference point, because it is typically perceived as the most successful entrepreneurial economy worldwide.

Consequently, our analyses cover Austria, Belgium, Denmark, Finland, Germany, the Netherlands, Norway, Sweden, and Switzerland, described as typical CMEs in the VoC literature, as well as Ireland, the UK, and the US, considered to be typical LMEs. Furthermore, we include the Czech Republic, Hungary, Poland, the Slovak Republic, and Slovenia as the most researched EMEs, as well as France, Italy, Portugal, and Spain, constituting some of the most investigated MMEs (Molina and Rhodes 2007; Nölke and Vliegenthart 2009). ${ }^{1}$ Table 1 provides an overview of our country sample and its institutional classification in the $\mathrm{VoC}$ literature.

\footnotetext{
${ }^{1}$ Greece could not be included as an additional MME because of data insufficiencies.
} 
Table 1 Country sample and institutional classifications according to the VoC literature

\begin{tabular}{llll}
\hline CMEs & LMEs & EMEs & MMEs \\
\hline Austria & Ireland & Czech Republic & France \\
Belgium & The UK & Hungary & Italy \\
Denmark & The US & Poland & Portugal \\
Finland & & Slovakia & Spain \\
Germany & & Slovenia & \\
The Netherlands & & & \\
Norway & & & \\
Sweden & & & \\
Switzerland & & & \\
\hline
\end{tabular}

\subsection{Data-operationalization of institutions and entrepreneurship}

We operationalize the institutions that the $\mathrm{VoC}$ and entrepreneurship literature consider to be relevant for entrepreneurship as follows:

With regard to finance-related institutions, we measure the different corporate governance rights between countries using the indicator 'protection of minority interests' from the World Bank's Doing Business database. The indicator focuses on equity investors and, more precisely, on minority shareholders who have a share in losses and profits and a stake that is large enough to allow them to vote on important decisions, but not large enough to allow them to control the company. More concretely, the indicator captures shareholders' rights in corporate governance by distinguishing three dimensions of 'good governance' and three of 'bad governance'. ${ }^{2}$ Higher values on this 'protection of minority' index indicate a more direct involvement of shareholders in corporate governance (without the intermediation of a supervisory board) - and consequently, increased rights to hold managers directly accountable.

We measure differences in the minimum capital requirements between countries using the indicator 'paidin minimum capital' from the World Bank's Doing

\footnotetext{
${ }^{2}$ With regard to good governance practices, the indicator captures the following: (1) shareholders' rights and role in major corporate decisions; (2) governance safeguards protecting shareholders from undue board control; and (3) corporate transparency on ownership stakes, managerial compensation, and financial prospects. With regard to bad governance practices, the indicator measures the following: (1) transparency of transactions made; (2) shareholders' ability to sue and hold directors liable for self-dealing, and (3) access to evidence and allocation of legal expenses in shareholder litigation.
}

Business database. This measure captures the amount that the entrepreneur needs to deposit in a bank or with a notary in order to open up a limited liability company (or its legal equivalent). If there is more than one type of limited liability company in the economy, that limited liability form is chosen which is most common among domestic firms. This paid-in capital is recorded as a percentage of the economy's income per capita. We rescaled this indicator so that a higher score indicates lower minimum capital requirements, and vice versa.

The impact of different institutions on the availability of venture capital is measured using the indicator 'venture capital investments in start-up and seed companies' compiled by INVEST Europe and made available by Eurostat. ${ }^{3}$ The indicator measures the extent of venture capital investments in early-stage seed and start-up companies as a percentage of national GDP. ${ }^{4}$ Higher values indicate higher venture capital investments in start-up firms and thus increased opportunities for entrepreneurs to access venture funding.

Finally, we use the 'recovery rate' indicator from the World Bank's Doing Business database to measure the extent to which shareholders can defend their interests against creditors in case of corporate insolvency. The recovery rate is calculated based on the time, cost, and outcome of insolvency proceedings in each economy. ${ }^{5}$ The calculation takes into account the outcome: whether the business emerges from the proceedings as a going concern or the assets are sold piecemeal. Then, the costs of the proceedings are deducted (1 cent for each percentage point of the value of the debtor's assets). The cost includes court fees and government levies; fees for insolvency administrators, auctioneers, assessors, and lawyers; and all other fees and costs. Higher values indicate higher costs for creditors to recover their investment, favouring shareholders in case of corporate insolvency.

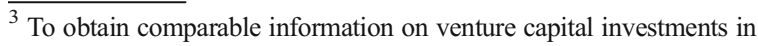
the United States, we used the OECD Entrepreneurship Financing Database.

${ }^{4}$ Thereby, investments at the seed stage are defined as financing provided to research, assess, and develop an initial concept before a business has reached the start-up phase. Investments at the start-up stage, in turn, are defined as finance that is provided - for product development and initial marketing, manufacturing, and sales - to those companies that are in the process of being set up or in business for a short time, but have not sold their product commercially.

${ }^{5}$ Time for creditors to recover their credit is recorded in calendar years. The period of time measured is from the company's default until the payment of some or all of the money owed to the bank.
} 
We use three different indicators to measure the short-term orientation of labour-market institutions: In line with the VoC literature, we use the 'regular employment protection legislation' indicator from the OECD employment database in order to measure labour-market flexibility of permanent employment. The indicator focuses on the conditions for terminating employment, including required notification and involvement of third parties (such as courts, labour inspectorates, and workers' councils), notice periods and severance pay, the conditions under which it is permissible to lay off an employee, and the repercussions if a dismissal is found to be unfair. Furthermore, the indicator also takes into account provisions for collective dismissals. Higher scores indicate more rigid labour market institutions, i.e. stronger protection for permanent employment, indicating greater difficulty in hiring and firing permanent workforces in the short run.

To measure the institutionalised flexibility of temporary employment, we use the indicator 'temporary employment protection legislation' from the OECD employment database. The indicator measures the strictness of regulation on the use of fixed-term and temporary work agency contracts, including valid cases for the use of fixed-term contracts, the maximum number and cumulated duration of successive fixed-term contracts, the types of work for which temporary work agency (TWA) employment is legal, as well as the restrictions on the number and maximum cumulated duration of renewals of TWA assignments. Higher scores indicate stronger protection for temporary employment, indicating greater difficulty in hiring and firing temporary workforces in the short run.

Finally, we take the indicator 'social spending on start-up incentives' from the OECD database on 'labour market programmes' to measure the extent of programmes that promote entrepreneurship by encouraging the unemployed and target groups to start their own businesses or become self-employed. The indicator is calculated as a percentage of national GDP, so that higher values indicate more developed entrepreneurship programmes.

In line with our theoretical reasoning, we use three different indicators to assess how education and training-related institutions influence the extent of scientific knowledge available to entrepreneurial ventures. From the OECD database on education, we take the indicator "population with tertiary education' in order to measure the extent to which national education systems facilitate the acquisition of general skills by future workforces. The indicator reports the percentage of the population aged 2564 years with a tertiary degree, so that higher values indicate a higher share of generally skilled workforces and thus a better skill base for Schumpeterian entrepreneurial ventures.

From the OECD database on science and technology indicators, we use the indicator 'researchers per head' to assess the extent to which institutions facilitate the availability of scientific knowledge to entrepreneurial ventures. This measure indicates the share of scientists active in research and development activities, expressed per thousand people employed.

From the Global Entrepreneurship Monitor (GEM), we employ the indicator 'R\&D transfer' in order to assess the extent to which national $R \& D$ activities lead to new commercial opportunities and are available to SMEs. The indicator is a composite index, reporting (1) to what extent new technology, science, and other knowledge are efficiently transferred from universities and public research centres to new and growing firms; (2) to what extent small firms have just as much access to new research and technology as large, established firms; (3) to what extent new and growing firms can afford the latest technology; (4) to what extent there are adequate government subsidies for new and growing firms to acquire new technology; (5) to what extent the science and technology base efficiently supports the creation of new, world-class technology-based ventures; and (6) to what extent there is good support available for engineers and scientists to have their ideas commercialised through new and growing firms. Higher scores indicate a better institutional environment for research and development activities and thus, $\mathrm{R} \& \mathrm{D}$ transfer to entrepreneurial ventures.

With regard to institutions governing inter-firm collaborations, we use the indicator 'enforcing contracts' from the World Bank's Doing Business database in order to assess the extent to which institutions facilitate the enforcement of contracts between collaboration partners. This indicator reports the time and cost for resolving a commercial dispute through a local first-instance court and the quality of judicial processes index, evaluating whether each economy has adopted a series of good practices that promote quality and efficiency in the court system. 
Higher scores indicate a more supportive institutional environment for enforcing contracts.

We measure the reliability of a country's legal systems through four institutional indicators from the World Bank's Doing Business database. The indicator 'judicial independence' measures the independence of the judiciary from the political influences of members of government, citizens, and firms. The indicator 'impartial courts' reports to what extent the efficiency and objectivity of government regulations in settling disputes and challenges is related to private businesses. The indicator 'protection of property rights' assesses to what extent private property rights, including financial ones and intellectual property, are protected by law. Lastly, 'integrity of the legal system' measures the strength and impartiality of the legal system and assesses popular observance of the law. Higher scores indicate a more reliable legal system.

Importantly, we (re-)scale all the institutional indicators in such a way that higher scores indicate a more supportive institutional environment for Schumpeterian entrepreneurship, so that the aforementioned hypotheses are confirmed if the institutional indicators are positively correlated with Schumpeterian forms of entrepreneurship.

In line with the theoretical illustrations in Section 2, we use different indicators to measure entrepreneurial activity at three different stages.

At the first stage, before the actual start of a new venture, we take the perception of entrepreneurial opportunities as an indicator for Schumpeterian entrepreneurship. To measure this concept, we retrieved the indicator 'perceived opportunities' from the Global Entrepreneurship Monitor (GEM). This indicator reports the percentage of a country's population aged 18-64 who see good opportunities to start a firm in the next 6 months in the area where they live.

At the second stage, when the new venture is actually set up, we measure a venture's degree of innovativeness. To this end, we employ two sets of measurements, drawn from the Eurostat Business Demography database and from the OECD Structural Business Statistics database. Both databases provide information about firm activity in 2-digit manufacturing sectors, classified according to NACE Rev. 2 categories. The data enables us to distinguish firm activity according to its degree of technological intensity, whereby we take the sectoral level of technological intensity as a proxy for the venture's innovativeness - in line with the Eurostat (2008) classifications of NACE Rev. 2 categories into high-technology, medium-high-technology, medium-low-technology, and low-technology sectors.

The first set of measurements covers birth rates in manufacturing sectors, arguably a good measure of the prevalence of new venture activity. More specifically, we consider the births of enterprises in sectors of differing technological activity: in (i) high- and medium-high technology sectors, ${ }^{6}$ (ii) medium-low-technology sectors, and (iii) lowtechnology sectors.

The second set of measurements reports the growth in the total number of firms in manufacturing sectors, which enables us to account not only for births but also for corporate death rates and thus the overall turnover of firms. Again, we make a distinction based on innovativeness. Here, we look at the growth in the number of enterprises in (i) hightechnology manufacturing, (ii) medium-low technology manufacturing, and (iii) low-technology manufacturing sectors.

At a third stage, we measure the growth aspirations of entrepreneurs during the early life of a new venture. To this end, we again consult the GEM database and retrieve the measurement 'growth expectation early-stage', which indicates the percentage of those involved in total early-stage entrepreneurial activity (individuals in the working age population who are actively involved in business start-ups, either in the phase of starting a new firm or in the phase spanning 42 months after the birth of the firm) who expect to employ at least five employees 5 years from now. In the following section, we rename this variable 'high-growth'.

In our regression analysis, we also control for the level of economic development by including the log of GDP per capita and labour force participation rates at the national level. The latter is calculated as the labour force divided by the total working-age population, referring to people aged 15 to 64 . Both indicators are drawn from OECD databases on 'Productivity and Employment', respectively.

Table 2 provides an overview of the (independent) institutional variables, the (dependent) entrepreneurship

\footnotetext{
${ }^{6}$ Due to the manner in which the data is aggregated, we needed to combine these two sectors.
} 
Table 2 Overview and descriptive statistics of indicators used in the analyses (21 Western countries)

\begin{tabular}{|c|c|c|c|c|c|}
\hline & Min & Max & Mean & $\mathrm{sd}$ & Year coverage \\
\hline \multicolumn{6}{|c|}{ Finance-related Institutions } \\
\hline Protection of minority interests & 30 & 86.67 & 58.51 & 13.56 & 2006-2014 \\
\hline Minimum capital requirements & 0 & 247.4 & 218.1 & 36.3 & 2004-2014 \\
\hline Venture capital investment & 0 & 0.073 & 0.017 & 0.015 & $2007-2012$ \\
\hline Recovery rate & 15.4 & 94.4 & 67.4 & 20.3 & 2004-2014 \\
\hline \multicolumn{6}{|c|}{ Labour-market institutions } \\
\hline Regular employment protection legislation & 1.000 & 3.980 & 2.482 & 0.553 & 2004-2014 \\
\hline Temporary employment protection legislation & 0.250 & 3.630 & 2.325 & 0.874 & 2004-2014 \\
\hline Social spending on start-up incentives & 0 & 0.15 & 0.13 & 0.03 & 2004-2014 \\
\hline \multicolumn{6}{|c|}{ Education- and training-related institutions } \\
\hline$\%$ population with tertiary education & 12.22 & 43.91 & 27.81 & 8.63 & $2005-2013$ \\
\hline Researchers per head & 2.96 & 17.27 & 7.90 & 3.01 & 2004-2013 \\
\hline$R \& D$ transfer & 1.87 & 3.65 & 2.61 & 0.35 & 2004-2013 \\
\hline \multicolumn{6}{|c|}{ Institutions governing inter-firm relations } \\
\hline Enforcing contracts & 34.66 & 81.6 & 69.27 & 10.24 & 2004-2014 \\
\hline Judicial independence & 2.1 & 9.38 & 6.95 & 1.91 & 2004-2014 \\
\hline Impartial courts & 1.89 & 9.25 & 5.82 & 1.97 & 2004-2014 \\
\hline Protection of property rights & 4.08 & 9.61 & 7.41 & 1.42 & 2004-2014 \\
\hline Integrity of the legal system & 5.97 & 10 & 8.58 & 1.18 & 2004-2014 \\
\hline \multicolumn{6}{|c|}{ Entrepreneurship indicators } \\
\hline Perceived opportunity & 2.850 & 71.495 & 34.648 & 14.180 & 2004-2014 \\
\hline Births in high-tech and medium-high-tech sectors & 0.032 & 0.268 & 0.115 & 0.054 & $2005-2014$ \\
\hline Births in medium-low-tech sectors & 0.219 & 0.575 & 0.367 & 0.073 & 2005-2014 \\
\hline Births in low-tech sectors & 0.368 & 0.729 & 0.516 & 0.081 & $2005-2014$ \\
\hline Growth in high-tech sectors & -0.353 & 0.234 & -0.011 & 0.061 & 2009-2014 \\
\hline Growth in medium-low-tech sectors & -0.096 & 0.133 & 0.002 & 0.041 & 2009-2014 \\
\hline Growth in low-tech sectors & -0.138 & 0.226 & -0.005 & 0.048 & 2009-2014 \\
\hline High-growth aspirations & 0.000 & 44.009 & 24.829 & 7.600 & 2004-2014 \\
\hline \multicolumn{6}{|c|}{ Control variables } \\
\hline $\ln$ GDP & 9.499 & 11.113 & 10.457 & 0.315 & 2004-2014 \\
\hline Share of the labour force & 60.459 & 83.761 & 72.878 & 5.469 & $2004-2014$ \\
\hline
\end{tabular}

variables, and the control variables to be used in the following analyses. All our institutional and entrepreneurship variables are measured at the country level of the 21 Western countries and-in line with data availability - as the average of the 2004-2014 time span. ${ }^{7}$

\footnotetext{
${ }^{7}$ In order to identify possible changes that may have taken place in the countries' institutional environments over time, we also split our data into two groups: the periods of 2004-2009 and of 2009-2014 respectively. Importantly though, our separate analyses for these two time periods revealed that no major institutional changes have taken place as the results are very similar between the two periods. We therefore used the average of the 2004-2014 time span in the analyses and results presented below.
}

The actual year coverage for each variable is indicated in the last column of Table 2.

\subsection{Methods and models}

To test the propositions and hypotheses formulated in the theory section, we proceed in two steps.

In a first step, we use factor analyses, combined with cluster analyses, in order to test propositions P1-P5. To this end, we identify whether each country falls into a distinct group and, if so, how these groups look like with regard to their entrepreneurial 
institutions. Factor analysis is a variable reduction technique hinging on the idea that latent constructs (the factors) can be measured indirectly by determining their influence to responses on measured variables (Suhr 2005). Because all institutions discussed in the previous section can be considered latent variables with various components, factor analyses make it possible to assess whether the indicators we identified for each institutional dimension indeed load on just one factor or whether they measure more than one dimension. In preparing the factor analyses, given the slowly changing nature of institutional variables (Jackson and Deeg 2012), we take the average of the institutional indicators between 2004 and 2014. We then standardise each variable using their $z$-scores to avoid a situation in which variables with a high standard deviation get more weight than variables with low standard deviation.

We use the factor scores obtained from these factor analyses as an input for cluster analyses at the country level. In doing so, we first run cluster analyses for each institutional dimension separately, as this tells us to what extent countries fall into different groups with regard to their finance-related, labour-market, education and training institutions, and institutions governing inter-firm collaborations. More concretely, this shows us to what extent countries fall into groups that are similar to the institutional constellations (CMEs, LMEs, MMEs, and EMEs) identified in the $\mathrm{VoC}$ literature. To assess Proposition 5 on institutional complementarity, we then also run cluster analyses for all institutional dimensions jointly using the factor scores obtained for each institutional indicator. If the institutional constellations observed for all dimensions jointly are more in line with the VoC country groups (CMEs, LMEs, MMEs, and EMEs) than the separate institutional dimensions, we take this as an indication of institutional complementarity.

Having identified distinct groups of institutional constellations, we test hypotheses $\mathrm{H} 1-\mathrm{H} 5$ in a second step by assessing how these constellations translate into different forms of entrepreneurship. To this end, we run simple OLS regressions revealing the relevance of the different institutional constellations identified in step one (independent variables) for different types of entrepreneurship (dependent variables). Hence, we estimate the following model:

$$
\begin{aligned}
Y_{i t} & \alpha+\beta_{1} \text { Cluster }_{i}+\beta_{2} \ln \mathrm{GDP}_{i t}+\beta_{3} \text { laborforce }_{i t} \\
& +\beta_{4} \theta_{t}+e_{i t}
\end{aligned}
$$

where $Y$ is our entrepreneurship indicators at time $t$ for country $i$ and $\alpha$ is the constant. Cluster ${ }_{i}$ represents the dummy variables capturing the membership of country $i$ in a certain cluster considering the varieties in the $\mathrm{VoC}$ framework, and underlying clusters created based on its four principal dimensions - namely finance-related institutions, labour, education and inter-firm. To create the dummy variables, we rely on results obtained from the cluster analysis and dendograms. In our regression analyses, we also control for the variables log GDP per capita and labour force participation.

\section{Analyses and findings}

\subsection{Factor and cluster analyses}

Table 3 reports results from separate factor analyses for each of the institutional dimensions described above. For each institutional aspect considered, only the first factor has an Eigen-value close to or greater than 1.0 (the traditional cut-off point; Kaiser 1960). Furthermore, all variables included only load meaningfully on the first factor. Given that they all load with a value of less than 0.1 on the second factor, we only report the first factor for each institutional dimension in Table 3.

The first factor on finance-related institutions has an Eigen-value of 1.75 and explains $44 \%$ of the variance in the data. All four variables load positively, whereby venture capital investment and recovery rate have the highest loadings. Overall, the variable loadings suggest that a higher value on this factor indicates more permissive finance-related institutions, whereas a lower value indicates a more constraining framework.

Turning to the labour-market institutions, the first factor here has an Eigen-value just below 1.0 and explains about one third (32\%) of the variance in the data, slightly less than a single observed variable. However, in all factor analyses where the trace of the correlation matrix is not used as the divisor for reported proportions, the Eigen-value for this factor is consistently higher than 1.0 and thus supports our choice of creating one factor for 
Table 3 Factor analyses: first factor for each institutional dimension

\begin{tabular}{|c|c|c|c|}
\hline & Eigen-value & Variance explained & Factor loadings \\
\hline Finance & 1.75 & 0.44 & \\
\hline Protection of minority interests & & & 0.60 \\
\hline Minimum capital requirements & & & 0.57 \\
\hline Venture capital investment & & & 0.74 \\
\hline Recovery rate & & & 0.71 \\
\hline Labour & 0.96 & 0.32 & \\
\hline Regular employment protection legislation & & & 0.61 \\
\hline Temporary employment protection legislation & & & 0.65 \\
\hline Social spending on start-up incentives & & & 0.41 \\
\hline Education & 1.45 & 0.48 & \\
\hline$\%$ Population with tertiary education & & & 0.80 \\
\hline Researchers per head & & & 0.64 \\
\hline $\mathrm{R} \& \mathrm{D}$ transfer & & & 0.64 \\
\hline Inter-firm & 4.04 & 0.81 & \\
\hline Enforcing contracts & & & 0.68 \\
\hline Judicial independence & & & 0.97 \\
\hline Impartial courts & & & 0.98 \\
\hline Protection of property rights & & & 0.98 \\
\hline Integrity of the legal system & & & 0.85 \\
\hline
\end{tabular}

the three labour-market indicators chosen. All three variables load positively, with temporary employment protection having the strongest loading. The variable loadings suggest that a higher value on this component indicates more flexible labour-market institutions, whereas a lower value is indicative of constraining institutions.

As for the institutions related to education and training, the first factor has an Eigen-value of 1.45 and explains roughly half $(48 \%)$ of the variance. All variables display positive loadings, whereby the percentage of population with tertiary education loads most strongly. We interpret this to the extent that higher scores indicate more facilitative institutions for the development of multi-tasking (general, scientific, entrepreneurial) skills.

Lastly, we observe the dimension of institutions governing inter-firm collaborations. Here, the first factor has an Eigen-value as high as 4.04 and explains no less than $81 \%$ of the variance, suggesting a strong degree of uniformity among the variables. Judicial independence, impartial courts, and protection of property rights load particularly strongly. A straightforward interpretation is that higher scores on this dimension indicate more reliable legal institutions that enable inter-firm collaboration.
As the next step, we undertake cluster analyses (Fig.1a-d), which are run on the basis of the four factors produced in the factor analyses. Table 4 shows the ranking of countries according to these four factors on finance, labour, education, and inter-firm dimensions and is used to provide background information on the cluster analysis. Figure 1a-d shows the results. The different colours in the graphs highlight the clusters of countries as defined in the earlier VoC literature. These results suggest that we may indeed be observing distinct institutional constellations supporting entrepreneurship in line with the VoC theory. This is particularly visible for finance-related and labour-market institutions, as well as for the countries considered to be LMEs (Ireland, the UK, and the US).

With regard to finance-related institutions, four distinct institutional constellations can be identified (Fig. 1a). The first one is formed by the LME economies (UK, Ireland, and the US) and is, unsurprisingly, characterised by permissive finance-related institutions, namely corporate governance rights that make managers directly accountable to shareholders, low minimum capital requirements, institutions that facilitate the availability of venture capital, and institutions that privilege shareholders in case of corporate failure by limiting the chances of creditors to 

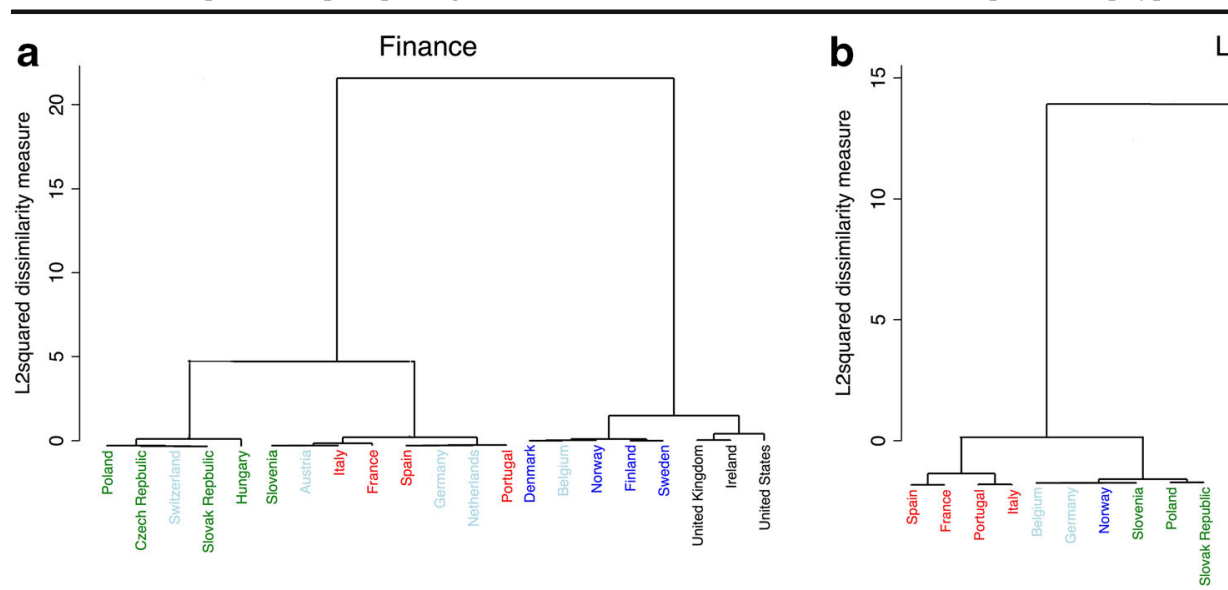

Labor

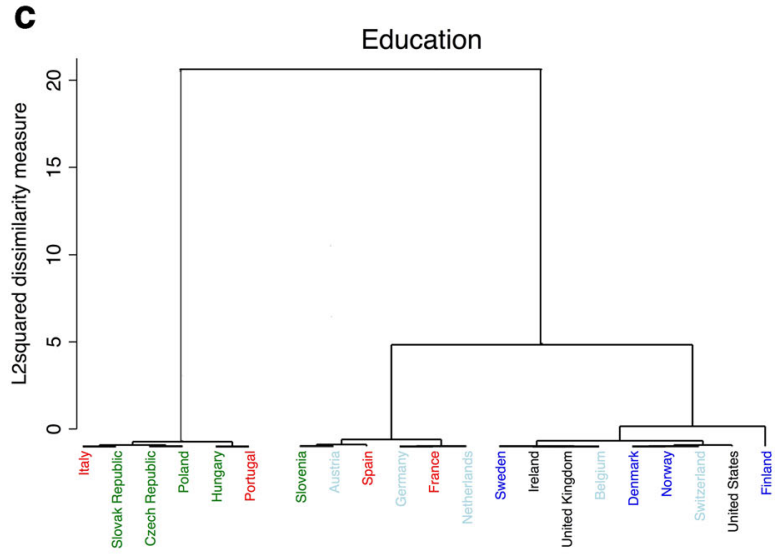

d

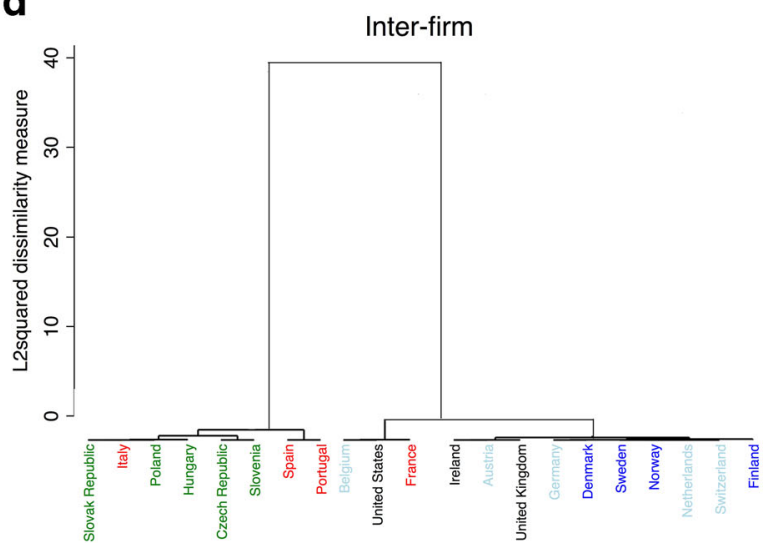

Fig. 1 a-d Clusters of countries along the four dimensions

recover their investments. The second institutional group consists of all Nordic CMEs and Belgium and offerswhat we term-somewhat permissive finance-related institutions. This second country group mainly differs from the first group in their more limited protection of minority investors and higher minimum capital requirements, whereas their facilitation of venture capital and favourable recovery rates are roughly on par.

The countries forming the third cluster of somewhat constraining finance-related institutions include mostly MMEs (Italy, France, Spain, Portugal) but also some of the 'traditional' Continental CMEs (Germany, the Netherlands, Austria, as well as Slovenia). This cluster is characterised by overall lower average levels on all four finance-related institutions compared to the somewhat permissive cluster, whereby this difference is least pronounced in terms of their minimum capital requirements. Finally, the fourth cluster includes mostly EMEs (Poland, Czech Republic, Slovak Republic, and Hungary, as well as Switzerland) and is characterised by constraining finance-related institutions: Out of all the country clusters, it scores most poorly on all four institutional aspects considered and is thus characterised by little protection of minority investors, high minimum capital requirements, little facilitation of venture capital, and a recovery rate favouring creditors over shareholders.

Taken together, this overview lends support to Proposition 1: finance-related institutions supporting entrepreneurship differ between countries in the extent to which they affect shareholders in their investment options.

Similarly, Proposition 2 is supported, as the graph in Fig. 1b shows that labour-market institutions supporting entrepreneurship differ between countries in the extent to which they facilitate the short-term engagement of workforces in entrepreneurial ventures. Overall, four distinct institutional constellations can be identified regarding labour-market institutions.

First, the LME countries (Ireland, UK, US) group together again, this time forming a cluster characterised by flexible labour-market institutions 
Table 4 Countries ranked according to factor scores in the four institutional dimensions. Gridlines distinguish clusters

\begin{tabular}{|c|c|c|c|c|c|c|c|}
\hline & Finance & & Labour & & Education & & Inter-firm \\
\hline United States & 1.66 & United States & 1.73 & Finland & 1.52 & Finland & 1.2 \\
\hline Ireland & 1.21 & United Kingdom & 1.23 & United States & 1.02 & Switzerland & 1.01 \\
\hline United Kingdom & 1 & Ireland & 0.97 & Switzerland & 0.87 & Netherlands & 0.99 \\
\hline Sweden & 0.78 & Switzerland & 0.52 & Norway & 0.8 & Norway & 0.97 \\
\hline Finland & 0.78 & Hungary & 0.36 & Denmark & 0.73 & Sweden & 0.97 \\
\hline Norway & 0.64 & Finland & 0.33 & Belgium & 0.65 & Denmark & 0.92 \\
\hline Belgium & 0.61 & Denmark & 0.3 & United Kingdom & 0.56 & Germany & 0.86 \\
\hline Denmark & 0.47 & Sweden & 0.2 & Ireland & 0.55 & United Kingdom & 0.79 \\
\hline Portugal & 0.05 & Netherlands & 0.18 & Sweden & 0.52 & Austria & 0.72 \\
\hline Netherlands & -0.07 & Austria & 0.13 & Netherlands & 0.16 & Ireland & 0.68 \\
\hline Germany & -0.08 & Czech Republic & 0.13 & France & 0.07 & France & 0.22 \\
\hline Spain & -0.17 & Slovak Republic & -0.1 & Germany & 0.02 & United States & 0.09 \\
\hline France & -0.3 & Poland & -0.26 & Spain & -0.11 & Belgium & 0.04 \\
\hline Italy & -0.36 & Slovenia & -0.38 & Austria & -0.26 & Portugal & -0.68 \\
\hline Austria & -0.37 & Norway & -0.42 & Slovenia & -0.47 & Spain & -0.78 \\
\hline Slovenia & -0.65 & Germany & -0.44 & Portugal & -0.85 & Slovenia & -1.11 \\
\hline Hungary & -0.89 & Belgium & -0.46 & Hungary & -0.96 & Czech Republic & -1.16 \\
\hline Slovak Republic & -0.98 & Italy & -0.65 & Poland & -1.07 & Hungary & -1.18 \\
\hline Switzerland & -1.03 & Portugal & -0.86 & Czech Republic & -1.12 & Poland & -1.32 \\
\hline Czech Republic & -1.15 & France & -1.18 & Slovak Republic & -1.3 & Italy & -1.58 \\
\hline Poland & -1.54 & Spain & -1.32 & Italy & -1.33 & Slovak Republic & -1.65 \\
\hline
\end{tabular}

with weak regular and temporary employment protection and high levels of social spending on start-up incentives. A second group clusters together based on their somewhat rigid labour-market institutions and mainly consists of Nordic CMEs (Sweden, Denmark, and Finland together with Austria, the Netherlands, and Switzerland, as well as the Czech Republic and Hungary). While this group has fairly similar spending levels on start-up incentives, its regular and temporary employment protection is considerably stronger than in flexible labour markets.

A third group of countries is characterised by - what we term-rigid labour-market institutions and includes most EMEs (Slovenia, Poland, Slovak Republic) but also Germany, Belgium, and Norway. Employment protection, especially of the temporary type, is stronger than in the somewhat rigid group, and their entrepreneurship programmes are less developed. The last group can be described as having constraining labour-market institutions and includes all MMEs (Spain, France, Portugal, and Italy). While the latter are roughly on par with the third group in terms of public start-up initiative offers, both permanent and temporary employment protection are considerably stronger.

We also find support for Proposition 3: Educationand training-related institutions supporting entrepreneurship differ between countries in the extent to which they facilitate the development of scientific knowledge. Here, three distinct country clusters emerge (Fig.1c). First, a cluster characterised by scientific education systems, composed of all LMEs (Ireland, UK, and US) and all Nordic CMEs (Sweden, Denmark, Norway, Finland), as well as Switzerland. This group is characterised by a high percentage of people with tertiary degrees, high shares of researchers, and high levels of R\&D transfer. The second cluster scores systematically lower on all these institutional variables and is thus characterised by more vocational education systems. This cluster includes most continental CMEs (Austria, Germany, the Netherlands) as well as France, Spain, and Slovenia. The third country group - including most EMEs (Slovak Republic, Czech Republic, Poland, Hungary) as well as Italy and Portugal - stands out because of its low levels of people with tertiary degrees, limited numbers of 
Fig. 2 The VoC framework: all indicators clustered together
The VoC framework

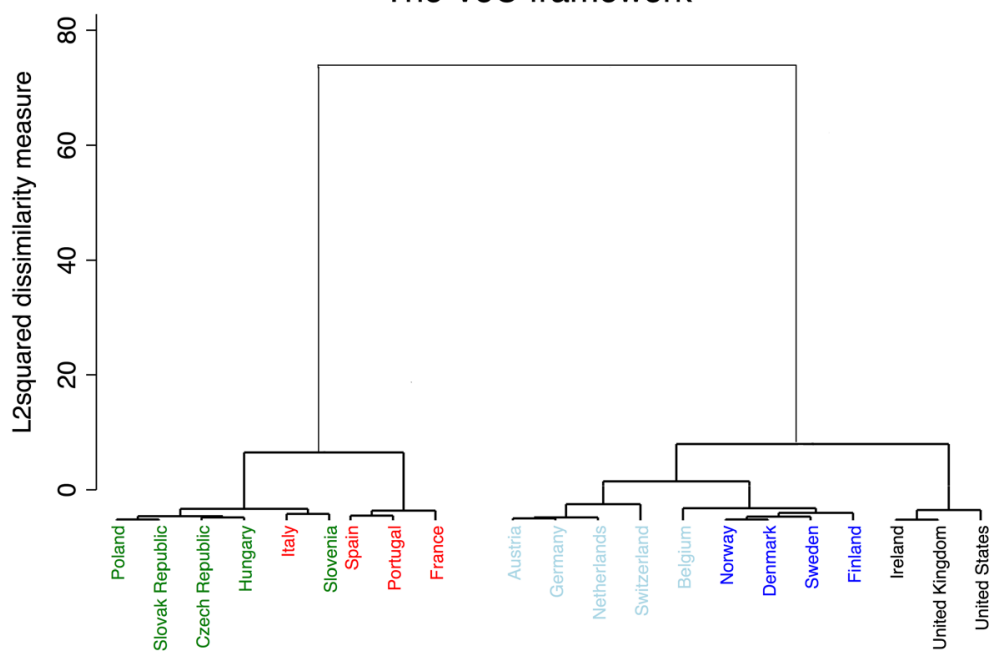

researchers, and low levels of $R \& D$ transfer. It is thus characterised by fairly basic education systems.

With regard to institutions governing inter-firm collaborations, only two clusters emerge (see Fig.1d). The first is characterised by reliable legal institutions and consists of all LMEs (US, Ireland, UK) and all CMEs (Belgium, Austria, Germany, Denmark, Sweden, Norway, Netherlands, Switzerland, and Finland) as well as France. Countries in this cluster score highly on all five institutional indicators included. The opposite applies to the second cluster, which is characterised by its unreliable legal institutions. Including all EMEs (Slovak Republic, Poland, Hungary, Czech Republic, and Slovenia) and almost all MMEs (Italy, Spain, Portugal), these countries have low average scores on all five institutional indicators. Overall, this lends support to Proposition 4, as institutions governing inter-firm relations differ notably between countries in the extent to which they facilitate the propensity of R\&D collaborations between companies.

A cluster analysis at the aggregate level of all institutional indicators sheds light on the idea of institutional complementarity suggested in Proposition 5. Figure 2 lends empirical support to this proposition, as the $\mathrm{VoC}$ country clusters identified for each institutional dimension separately emerge strongly as soon as all institutions are clustered together. With the exception of Italy (showing the institutional characteristics of an EME rather than an MME), four distinct country clusters emerge, in line with the predictions of the VoC literature - namely LMEs (Ireland, the UK, and the US), CMEs (Austria, Netherlands, Germany, Switzerland, Belgium, Sweden, Norway, and Finland), MMEs (France, Portugal, and Spain), and EMEs (Czech Republic, Hungary, Poland, Slovak Republic, Slovenia, as well as the aforementioned Italy).

Table 4, which ranks countries according to their scores along all four dimensions, shows that the LME countries stand out for their finance and labour-market flexibility, their scientific education systems providing workforces with multi-tasking skills, as well as their reliable legal systems. The institutional characteristics of CMEs are more mixed; overall, they have either somewhat permissive or somewhat constraining financial institutions, a fairly rigid (or well regulated) labour market, partly scientific and partly vocational education systems, as well as reliable legal institutions. Meanwhile, the MMEs and the EMEs are generally characterised by less supportive institutions, whereby MMEs are characterised by somewhat constraining financial markets, highly constraining labour markets, vocational or basic education systems, and unreliable legal institutions. The EMEs, for their part, mostly have constraining financial institutions, rigid labour markets, mainly basic education systems, and unreliable legal institutions.

\subsection{Varieties of entrepreneurship (regression results)}

Do these distinct institutional families actually support different types of entrepreneurship? Overall, the regression results confirm this idea, which is illustrated by Table 5, whereby LMEs serve as the reference category for the four overall country clusters. Each column presents a model with a different dependent variable. In Tables 10, 11, 12 in the Appendix, we let the three other clusters serve as reference categories. Broadly speaking, the results 
indicate that more flexible institutional environments (characteristic for LMEs) facilitate Schumpeterian forms of entrepreneurship. The main exception to this rule concerns perceived entrepreneurial opportunities, which, as mentioned, occur before any actual steps towards entrepreneurship are taken. Model 1 reveals that about $6 \%$ more people perceive business opportunities in the more rigid CMEs than in the flexible LMEs, and that only in the very rigid MMEs do fewer people perceive good opportunities than in the LMEs. Indeed, Table 11, where MMEs serve as a base case, shows that people in MMEs are the most pessimistic about possible business opportunities. Table 10, where CMEs serve as the base category, further elucidates that people in CMEs outrank their counterparts in all other economies in the extent to which they perceive business opportunities. As we shall see, however, this optimism on the part of potential CME entrepreneurs does not fully translate into the creation of Schumpeterian entrepreneurial ventures.

Models 2-7 show differences in the extent of Schumpeterian entrepreneurship at the second stage, i.e. at the moment of actual venture creation, in considering the degree of innovativeness of the new ventures. Here, the predictions of the $\mathrm{VoC}$ model are well applicable. When it comes to corporate birth rate (models 24), we see that entrepreneurs in CMEs create more low-tech ventures than LMEs, whereas entrepreneurs in MMEs do so to an even greater extent. While the entrepreneurs of LMEs and CMEs seem equally prone to creating high tech ventures, we see that EMEs and MMEs have fewer high-tech births than LMEs.

The Appendix tables confirm that entrepreneurs in CMEs create more high-tech ventures than entrepreneurs in EMEs and MMEs (Table 10). After the LMEs, CMEs hence stand out as the second most innovative country group, a fact that lends support to the argument that increasing flexibility leads to increasingly Schumpeterian forms of entrepreneurship and furthermore, that a well-regulated institutional environment supports incremental innovations. Entrepreneurs in MMEs outperform entrepreneurs in all other economies in the extent to which they set up low-tech ventures, but hardly set up any high-tech or medium-high-tech ventures compared to their counterparts in other economies (Table 11). Furthermore, while EME entrepreneurs are outperformed by entrepreneurs in both LMEs and CMEs in setting up high-tech ventures, they are decisively better at setting up medium-low-tech ventures than their counterparts in CMEs and MMEs (Table 12).

As regards the overall sector growth (models 5-7), the relationships are weaker (and the R2 is substantially lower). In our view, this suggests that the specialisation effects in different forms of entrepreneurship largely disappear if we not only consider the entry but also the

Table 5 VoC framework. Regressions with the identified clusters as core explanatory variables. LMEs serve as the base case

\begin{tabular}{|c|c|c|c|c|c|c|c|c|}
\hline & $\begin{array}{l}\text { (1) } \\
\text { Perceived } \\
\text { Opportunity }\end{array}$ & $\begin{array}{l}\text { (2) } \\
\text { Births in high-tech } \\
\text { and medium-high- } \\
\text { tech sectors }\end{array}$ & $\begin{array}{l}\text { (3) } \\
\text { Births in } \\
\text { medium-low- } \\
\text { tech sectors }\end{array}$ & $\begin{array}{l}\text { (4) } \\
\text { Births in } \\
\text { low-tech } \\
\text { sectors }\end{array}$ & $\begin{array}{l}\text { (5) } \\
\text { Growth in } \\
\text { high-tech } \\
\text { sectors }\end{array}$ & $\begin{array}{l}\text { (6) } \\
\text { Growth in } \\
\text { medium-low- } \\
\text { tech sectors }\end{array}$ & $\begin{array}{l}\text { (7) } \\
\text { Growth in } \\
\text { low-tech } \\
\text { sectors }\end{array}$ & $\begin{array}{l}(8) \\
\text { High- } \\
\text { growth } \\
\text { aspirations }\end{array}$ \\
\hline \multirow[t]{2}{*}{ CMEs } & $6.11 * *$ & -0.01 & -0.04 & $0.06 * * *$ & 0.01 & 0.00 & $0.02 *$ & $-9.52 * * *$ \\
\hline & $(3.06)$ & $(0.03)$ & $(0.04)$ & $(0.02)$ & $(0.02)$ & $(0.01)$ & $(0.01)$ & $(2.53)$ \\
\hline \multirow[t]{2}{*}{ EMEs } & 2.42 & $-0.08 * *$ & 0.06 & 0.03 & -0.01 & 0.00 & $0.04 * *$ & -1.64 \\
\hline & $(4.75)$ & $(0.03)$ & $(0.05)$ & $(0.03)$ & $(0.02)$ & $(0.02)$ & $(0.02)$ & $(4.88)$ \\
\hline \multirow[t]{2}{*}{ MMEs } & $-4.81 * *$ & $-0.11 * * *$ & $-0.08 *$ & $0.20 * * *$ & $-0.04 *$ & -0.02 & 0.01 & $-10.12 * * *$ \\
\hline & $(2.76)$ & $(0.03)$ & $(0.05)$ & $(0.05)$ & $(0.02)$ & $(0.03)$ & $(0.02)$ & $(3.54)$ \\
\hline \multirow[t]{2}{*}{$\ln$ GDP } & $13.22 *$ & -0.04 & -0.02 & 0.05 & -0.07 & 0.00 & 0.03 & -1.38 \\
\hline & $(8.05)$ & $(0.04)$ & $(0.06)$ & $(0.04)$ & $(0.05)$ & $(0.04)$ & $(0.03)$ & $(6.39)$ \\
\hline \multirow{2}{*}{$\begin{array}{l}\text { Share of the } \\
\text { labour } \\
\text { force }\end{array}$} & $0.88 * *$ & 0.00 & $0.00^{*}$ & $-0.01 * * *$ & $0.00^{*}$ & 0.00 & 0.00 & 0.26 \\
\hline & $(0.35)$ & $(0.00)$ & $(0.00)$ & $(0.00)$ & $(0.00)$ & $(0.00)$ & $(0.00)$ & $(0.23)$ \\
\hline \multirow[t]{2}{*}{ Constant } & $-166.99 * *$ & 0.47 & 0.26 & 0.34 & 0.41 & -0.09 & $-0.47 *$ & 26.06 \\
\hline & (89.34) & $(0.45)$ & $(0.61)$ & $(0.37)$ & $(0.69)$ & $(0.32)$ & $(0.28)$ & $(59.91)$ \\
\hline Observations & 190 & 185 & 185 & 185 & 117 & 108 & 104 & 190 \\
\hline R-squared & 0.518 & 0.521 & 0.363 & 0.568 & 0.132 & 0.106 & 0.223 & 0.303 \\
\hline
\end{tabular}


exit rates of new ventures. This, in turn, seems to indicate that more Schumpeterian ventures are also more prone to failure than less Schumpeterian ventures. Those patterns that remain are, however, roughly similar to what we have seen: CMEs and now also (and especially) EMEs see higher growth than LMEs in low-tech manufacturing sectors, whereas MMEs appear to be seeing somewhat less high-tech sector growth than LMEs, as could be expected.

Finally, model 8 considers the third stage of entrepreneurial ventures, namely the growth aspirations of entrepreneurs after venture creation. We see that in the more rigid CMEs and MMEs, these aspirations are significantly lower than in the more flexible LMEs, where the proportion of entrepreneurs with growth aspirations is about 10 percentage points higher. It is also noteworthy that the growth ambitions of entrepreneurs in EMEs do not differ substantially from those in LMEs.

To summarise, these results lend support to the VoC arguments in that LMEs - characterised by permissive finance-related institutions, flexible labour-market institutions, scientific education systems, and reliable legal institutions - have the most favourable institutional environment to stimulate Schumpeterian forms of entrepreneurship during and after venture creation. Only in the stage before venture creation is this not entirely the case. Additionally, it appears that the (well-) regulated institutions of CMEs support more incrementally innovative forms of entrepreneurship, while the constraining framework of EMEs makes entrepreneurs specialise in low-tech. Entrepreneurs in MMEs, meanwhile, are the least innovative.

To what extent are these overall findings underpinned by the different institutional dimensions we consider? Table 6 provides an overview of the four finance-related clusters we identified, whereby the permissive financial institutions of LMEs serve as the reference group. Model 1 illustrates that people perceive more business opportunities in countries with somewhat permissive financial institutions, in line with the results of Table 5. Regarding birth rates (models 2-4), results suggest that entrepreneurs operating under somewhat permissive and somewhat constraining financial institutions start more lowtech ventures than entrepreneurs operating under permissive institutions. That being said, few significant differences can be reported in terms of high-tech and mediumlow-tech births, suggesting that the degree of flexibility of financial institutions is of limited importance for enabling radically innovative entrepreneurship. Also, with regard to sector growth (models 5-7), the main difference seems to be that somewhat constraining and constraining financial institutions facilitate more low-technology manufacturing than permissive financial institutions. Finally, we see that entrepreneurial growth aspirations (model 8) are higher among entrepreneurs under the most permissive financial institutions, but entrepreneurs operating under constraining financial institutions seem to have more high-growth ambitions than entrepreneurs under somewhat permissive and somewhat constraining financial institutions. A takeaway from Table 6 is that finance-related institutions seem to influence entrepreneurial ventures most strongly in their final stage, as they most significantly influence the growth ambitions of entrepreneurs. Overall, these results confirm Hypothesis 1: The less finance-related institutions affect shareholders, the more Schumpeterian are the types of entrepreneurship that develop in the respective countries.

Table 7 reports how the four labour-related institutional constellations facilitate distinct forms of entrepreneurship. Again, flexible labour-market institutions (characteristic for LMEs) serve as the reference group. As can be seen in model 1, people who operate under somewhat rigid labour markets seem to perceive more business opportunities compared to those operating under flexible labour markets. As for the birth rate (Models 2-4), the entrepreneurs operating under flexible labour market institutions appear to create fewer low-tech ventures than entrepreneurs in any of the other groups, whereas entrepreneurs operating in constraining labour markets do so to the greatest extent. By contrast, entrepreneurs in flexible labour market institutions appear to create more high-tech and medium-low-tech ventures than their counterparts who operate in constraining labour market settings. Also for sector growth (models 57), the main difference seems to be that countries with somewhat constraining and rigid labour-market institutions see more low-technology manufacturing than the LMEs. And as for growth aspirations (model 8), we see that they are highest among entrepreneurs operating in the most flexible labour markets, but akin to the results in Table 6, entrepreneurs operating under rigid labour market institutions seem to have more high-growth ambitions than their counterparts in rigid and constraining labour market settings. Overall, these results confirm Hypothesis 2, i.e. that the more labour market institutions facilitate the short-term engagement of workforces in entrepreneurial ventures, the more Schumpeterian are 
Table 6 Regressions with the identified finance-related clusters as core explanatory variables. Permissive financial countries serve as the base case

\begin{tabular}{|c|c|c|c|c|c|c|c|c|}
\hline & $\begin{array}{l}\text { (1) } \\
\text { Perceived } \\
\text { Opportunity }\end{array}$ & $\begin{array}{l}\text { (2) } \\
\text { Births in high- } \\
\text { tech and medium- } \\
\text { high-tech sectors }\end{array}$ & $\begin{array}{l}(3) \\
\text { Births in } \\
\text { medium- } \\
\text { low-tech } \\
\text { sectors }\end{array}$ & $\begin{array}{l}\text { (4) } \\
\text { Births in } \\
\text { low-tech } \\
\text { sectors }\end{array}$ & $\begin{array}{l}\text { (5) } \\
\text { Growth in } \\
\text { high-tech } \\
\text { sectors }\end{array}$ & $\begin{array}{l}\text { (6) } \\
\text { Growth in } \\
\text { medium- } \\
\text { low-tech sec- } \\
\text { tors }\end{array}$ & $\begin{array}{l}\text { (7) } \\
\text { Growth } \\
\text { in low- } \\
\text { tech sec- } \\
\text { tors }\end{array}$ & $\begin{array}{l}\text { (8) } \\
\text { High- } \\
\text { growth } \\
\text { aspirations }\end{array}$ \\
\hline $\begin{array}{l}\text { Somewhat permissive } \\
\text { finance-related institu- } \\
\text { tion (mostly Nordic } \\
\text { CMEs) }\end{array}$ & $\begin{array}{c}11.51 * * * \\
(3.13)\end{array}$ & $\begin{array}{l}-0.04 \\
(0.04)\end{array}$ & $\begin{array}{l}-0.01 \\
(0.03)\end{array}$ & $\begin{array}{c}0.06 * * * \\
(0.02)\end{array}$ & $\begin{array}{l}-0.01 \\
(0.01)\end{array}$ & $\begin{array}{l}-0.01 \\
(0.01)\end{array}$ & $\begin{array}{c}0.01 \\
(0.01)\end{array}$ & $\begin{array}{c}-8.16^{* * * *} \\
(2.78)\end{array}$ \\
\hline $\begin{array}{l}\text { Somewhat constraining } \\
\text { finance-related institu- } \\
\text { tion (mostly MMEs) }\end{array}$ & $\begin{array}{l}-2.30 \\
(2.11)\end{array}$ & $\begin{array}{l}-0.04 \\
(0.04)\end{array}$ & $\begin{array}{c}-0.05^{*} \\
(0.03)\end{array}$ & $\begin{array}{c}0.11 * * * \\
(0.03)\end{array}$ & $\begin{array}{c}0.01 \\
(0.02)\end{array}$ & $\begin{array}{c}0.00 \\
(0.02)\end{array}$ & $\begin{array}{c}0.03 * * \\
(0.01)\end{array}$ & $\begin{array}{c}-9.55 * * * \\
(2.68)\end{array}$ \\
\hline $\begin{array}{l}\text { Constraining finance } \\
\text { related institution } \\
\text { (EMEs) }\end{array}$ & $\begin{array}{l}-1.25 \\
(2.96)\end{array}$ & $\begin{array}{l}-0.03 \\
(0.04)\end{array}$ & $\begin{array}{c}0.04 \\
(0.05)\end{array}$ & $\begin{array}{c}0.01 \\
(0.05)\end{array}$ & $\begin{array}{c}0.01 \\
(0.02)\end{array}$ & $\begin{array}{c}0.02 \\
(0.02)\end{array}$ & $\begin{array}{c}0.03 * * \\
(0.01)\end{array}$ & $\begin{array}{c}-5.80 * \\
(3.72)\end{array}$ \\
\hline $\ln$ GDP & $\begin{array}{l}10.26^{*} \\
(6.04)\end{array}$ & $\begin{array}{c}0.04 \\
(0.04)\end{array}$ & $\begin{array}{l}-0.02 \\
(0.07)\end{array}$ & $\begin{array}{l}-0.03 \\
(0.09)\end{array}$ & $\begin{array}{l}-0.03 \\
(0.04)\end{array}$ & $\begin{array}{c}0.04 \\
(0.03)\end{array}$ & $\begin{array}{c}0.04 \\
(0.03)\end{array}$ & $\begin{array}{l}-4.89 \\
(5.50)\end{array}$ \\
\hline Share of the labour force & $\begin{array}{l}0.85 * * \\
(0.34)\end{array}$ & $\begin{array}{l}0.00 * \\
(0.00)\end{array}$ & $\begin{array}{c}0.00 \\
(0.00)\end{array}$ & $\begin{array}{l}-0.00 \\
(0.00)\end{array}$ & $\begin{array}{l}0.00 * * \\
(0.00)\end{array}$ & $\begin{array}{l}-0.00 \\
(0.00)\end{array}$ & $\begin{array}{c}0.00 \\
(0.00)\end{array}$ & $\begin{array}{l}-0.01 \\
(0.19)\end{array}$ \\
\hline Constant & $\begin{array}{c}-134.62 * * * \\
(49.76)\end{array}$ & $\begin{array}{l}-0.49 \\
(0.41)\end{array}$ & $\begin{array}{l}0.51 \\
(0.66)\end{array}$ & $\begin{array}{c}1.00 \\
(0.85)\end{array}$ & $\begin{array}{c}0.01 \\
(0.40)\end{array}$ & $\begin{array}{l}-0.42 \\
(0.32)\end{array}$ & $\begin{array}{c}-0.50 * * \\
(0.25)\end{array}$ & $\begin{array}{l}81.81 * \\
(50.05)\end{array}$ \\
\hline Observations & 190 & 185 & 185 & 185 & 117 & 108 & 104 & 190 \\
\hline R-squared & 0.598 & 0.268 & 0.254 & 0.303 & 0.086 & 0.101 & 0.238 & 0.240 \\
\hline
\end{tabular}

Table 7 Regressions with the identified labour-related clusters as core explanatory variables. Countries with flexible labour markets serve as the base case

(1) (2) (3)

Perceived Births in high-tech Births in

Opportunity and medium-high- mediumtech sectors
(4) low-tech high-tech medium-low- low-tech growth low-tech sec- sectors sectors tech sectors sectors aspirations tors

\begin{tabular}{|c|c|c|c|c|c|c|c|c|}
\hline $\begin{array}{l}\text { Somewhat rigid } \\
\text { labour market } \\
\text { institution (Mostly } \\
\text { Nordic) }\end{array}$ & $\begin{array}{c}9.00 * * * \\
(3.44)\end{array}$ & $\begin{array}{l}-0.02 \\
(0.04)\end{array}$ & $\begin{array}{l}-0.03 \\
(0.03)\end{array}$ & $\begin{array}{c}0.07 * * * \\
(0.02)\end{array}$ & $\begin{array}{l}-0.00 \\
(0.02)\end{array}$ & $\begin{array}{c}0.01 \\
(0.01)\end{array}$ & $\begin{array}{l}0.02 * * \\
(0.01)\end{array}$ & $\begin{array}{c}-8.78 * * * \\
(3.00)\end{array}$ \\
\hline $\begin{array}{l}\text { Constraining labour } \\
\text { market institution } \\
\text { (MMEs) }\end{array}$ & $\begin{array}{l}-1.77 \\
(2.15)\end{array}$ & $\begin{array}{c}-0.08 * * \\
(0.04)\end{array}$ & $\begin{array}{c}-0.09 * * \\
(0.05)\end{array}$ & $\begin{array}{c}0.17 * * * \\
(0.04)\end{array}$ & $\begin{array}{c}-0.02 * \\
(0.02)\end{array}$ & $\begin{array}{c}-0.03 * \\
(0.02)\end{array}$ & $\begin{array}{c}0.01 \\
(0.01)\end{array}$ & $\begin{array}{c}-12.47 * * * \\
(2.74)\end{array}$ \\
\hline $\begin{array}{l}\text { Rigid labour market } \\
\text { institution } \\
\text { (EMEs+CMEs) }\end{array}$ & $\begin{array}{c}3.09 \\
(3.17)\end{array}$ & $\begin{array}{l}-0.04 \\
(0.04)\end{array}$ & $\begin{array}{c}0.02 \\
(0.04)\end{array}$ & $\begin{array}{l}0.03 * * \\
(0.02)\end{array}$ & $\begin{array}{l}0.03 * \\
(0.02)\end{array}$ & $\begin{array}{c}0.00 \\
(0.01)\end{array}$ & $\begin{array}{c}0.03 * * * \\
(0.01)\end{array}$ & $\begin{array}{c}-6.10 * * \\
(2.86)\end{array}$ \\
\hline $\ln$ GDP & $\begin{array}{c}21.60 * * * \\
(6.06)\end{array}$ & $\begin{array}{l}0.04 * \\
(0.03)\end{array}$ & $\begin{array}{l}-0.06 \\
(0.05)\end{array}$ & $\begin{array}{c}0.02 \\
(0.05)\end{array}$ & $\begin{array}{l}-0.04 \\
(0.03)\end{array}$ & $\begin{array}{c}0.01 \\
(0.02)\end{array}$ & $\begin{array}{c}0.01 \\
(0.02)\end{array}$ & $\begin{array}{c}-7.14 * * \\
(3.95)\end{array}$ \\
\hline $\begin{array}{l}\text { Share of the labour } \\
\text { force }\end{array}$ & $\begin{array}{c}0.57 * * \\
(0.27)\end{array}$ & $\begin{array}{c}0.00 \\
(0.00)\end{array}$ & $\begin{array}{l}-0.00 \\
(0.00)\end{array}$ & $\begin{array}{l}-0.00 \\
(0.00)\end{array}$ & $\begin{array}{l}0.00^{* *} \\
(0.00)\end{array}$ & $\begin{array}{l}-0.00 \\
(0.00)\end{array}$ & $\begin{array}{c}0.00 \\
(0.00)\end{array}$ & $\begin{array}{l}-0.02 \\
(0.20)\end{array}$ \\
\hline Constant & $\begin{array}{c}-232.37 * * * \\
(61.34)\end{array}$ & $\begin{array}{c}-0.38^{*} \\
(0.26)\end{array}$ & $\begin{array}{l}1.05^{* *} \\
(0.43)\end{array}$ & $\begin{array}{c}0.35 \\
(0.38)\end{array}$ & $\begin{array}{c}0.12 \\
(0.36)\end{array}$ & $\begin{array}{l}-0.13 \\
(0.14)\end{array}$ & $\begin{array}{c}-0.27^{*} \\
(0.18)\end{array}$ & $\begin{array}{c}105.99 * * * \\
(31.46)\end{array}$ \\
\hline Observations & 190 & 185 & 185 & 185 & 117 & 108 & 104 & 190 \\
\hline R-squared & 0.533 & 0.416 & 0.338 & 0.524 & 0.160 & 0.141 & 0.227 & 0.294 \\
\hline
\end{tabular}


Table 8 Regressions with the identified education-related clusters as core explanatory variables. Countries with scientific education systems serve as the base case

\begin{tabular}{|c|c|c|c|c|c|c|c|c|}
\hline & $\begin{array}{l}\text { (1) } \\
\text { Perceived } \\
\text { Opportunity }\end{array}$ & $\begin{array}{l}\text { (2) } \\
\text { Births in high-tech } \\
\text { and medium-high- } \\
\text { tech sectors }\end{array}$ & $\begin{array}{l}\text { (3) } \\
\text { Births in } \\
\text { medium-low- } \\
\text { tech sectors }\end{array}$ & $\begin{array}{l}\text { (4) } \\
\text { Births in } \\
\text { low-tech } \\
\text { sectors }\end{array}$ & $\begin{array}{l}\text { Growth in } \\
\text { high-tech } \\
\text { sectors }\end{array}$ & $\begin{array}{l}\text { (6) } \\
\text { Growth in } \\
\text { medium-low- } \\
\text { tech sectors }\end{array}$ & $\begin{array}{l}\text { (7) } \\
\text { Growth in } \\
\text { low-tech } \\
\text { sectors }\end{array}$ & $\begin{array}{l}(8) \\
\text { High- } \\
\text { growth } \\
\text { aspirations }\end{array}$ \\
\hline $\begin{array}{l}\text { Vocational } \\
\text { education } \\
\text { system } \\
\text { (CMEs) }\end{array}$ & $\begin{array}{l}-8.16^{* *} \\
(3.75)\end{array}$ & $\begin{array}{l}-0.02 \\
(0.03)\end{array}$ & $\begin{array}{l}-0.04 * * \\
(0.02)\end{array}$ & $\begin{array}{l}0.06^{*} \\
(0.04)\end{array}$ & $\begin{array}{l}0.02 \\
(0.02)\end{array}$ & $\begin{array}{l}0.02 * \\
(0.02)\end{array}$ & $\begin{array}{l}0.03 * * \\
(0.02)\end{array}$ & $\begin{array}{l}-3.91 * \\
(2.57)\end{array}$ \\
\hline $\begin{array}{l}\text { Basic education } \\
\text { system } \\
\text { (EMEs } \\
\text { +MMEs) }\end{array}$ & $\begin{array}{l}-6.58 \\
(5.44)\end{array}$ & $\begin{array}{l}-0.03 \\
(0.03)\end{array}$ & $\begin{array}{l}-0.02 \\
(0.05)\end{array}$ & $\begin{array}{l}0.06 \\
(0.07)\end{array}$ & $\begin{array}{l}0.01 \\
(0.02)\end{array}$ & $\begin{array}{l}0.01 \\
(0.03)\end{array}$ & $\begin{array}{l}0.01 \\
(0.02)\end{array}$ & $\begin{array}{l}-4.70 \\
(5.18)\end{array}$ \\
\hline $\ln$ GDP & $\begin{array}{l}9.68 \\
(8.74)\end{array}$ & $\begin{array}{l}0.02 \\
(0.04)\end{array}$ & $\begin{array}{l}-0.08 * \\
(0.05)\end{array}$ & $\begin{array}{l}0.06^{*} \\
(0.04)\end{array}$ & $\begin{array}{l}-0.02 \\
(0.05)\end{array}$ & $\begin{array}{l}0.03 \\
(0.04)\end{array}$ & $\begin{array}{l}0.03 \\
(0.03)\end{array}$ & $\begin{array}{l}-6.34 \\
(6.47)\end{array}$ \\
\hline $\begin{array}{l}\text { Share of the } \\
\text { Labour force }\end{array}$ & $\begin{array}{l}0.93 * * \\
(0.37)\end{array}$ & $\begin{array}{l}0.00 \\
(0.00)\end{array}$ & $\begin{array}{l}0.00 \\
(0.00)\end{array}$ & $\begin{array}{l}-0.00 \\
(0.01)\end{array}$ & $\begin{array}{l}0.00 * * \\
(0.00)\end{array}$ & $\begin{array}{l}-0.00 \\
(0.00)\end{array}$ & $\begin{array}{l}0.00 \\
(0.00)\end{array}$ & $\begin{array}{l}-0.15 \\
(0.30)\end{array}$ \\
\hline Constant & $\begin{array}{l}-128.49 * \\
(84.49)\end{array}$ & $\begin{array}{l}-0.18 \\
(0.45)\end{array}$ & $\begin{array}{l}1.12 * * \\
(0.51)\end{array}$ & $\begin{array}{l}0.02 \\
(0.38)\end{array}$ & $\begin{array}{l}-0.03 \\
(0.53)\end{array}$ & $\begin{array}{l}-0.35 \\
(0.36)\end{array}$ & $\begin{array}{l}-0.42 * \\
(0.31)\end{array}$ & $\begin{array}{l}102.16^{*} \\
(63.53)\end{array}$ \\
\hline Observations & 190 & 185 & 185 & 185 & 117 & 108 & 104 & 190 \\
\hline R-squared & 0.502 & 0.240 & 0.117 & 0.093 & 0.113 & 0.257 & 0.120 & 0.091 \\
\hline
\end{tabular}

the types of entrepreneurship that develop in the respective countries.

Meanwhile, in Table 8, we consider the three education-related institutional constellations as the main explanatory variables of interest. This time, the scientific education systems group (consisting of all LMEs and Nordic CMEs) serves as the reference group. As can be seen in model 1, people in countries with scientific education systems appear to perceive more opportunities than in the two other systems, with a significant difference relative to the vocational group. As for the birth rate (models 2-4),

Table 9 Regressions with the identified inter-firm-related clusters as core explanatory variables. Countries with reliable legal systems serve as the base case

\begin{tabular}{|c|c|c|c|c|c|c|c|c|}
\hline & $\begin{array}{l}\text { (1) } \\
\text { Perceived } \\
\text { Opportunity }\end{array}$ & $\begin{array}{l}\text { (2) } \\
\text { Births in high-tech } \\
\text { and medium-high- } \\
\text { tech sectors }\end{array}$ & $\begin{array}{l}\text { (3) } \\
\text { Births in } \\
\text { medium-low- } \\
\text { tech sectors }\end{array}$ & $\begin{array}{l}\text { (4) } \\
\text { Births in } \\
\text { low-tech } \\
\text { sectors }\end{array}$ & $\begin{array}{l}\text { Gr) } \\
\text { Growth in } \\
\text { high-tech } \\
\text { sectors }\end{array}$ & $\begin{array}{l}\text { (6) } \\
\text { Growth in } \\
\text { medium-low- } \\
\text { tech sectors }\end{array}$ & $\begin{array}{l}\text { (7) } \\
\text { Growth in } \\
\text { low-tech } \\
\text { sectors }\end{array}$ & $\begin{array}{l}(8) \\
\text { High- } \\
\text { growth } \\
\text { aspirations }\end{array}$ \\
\hline $\begin{array}{l}\text { Less reliable } \\
\text { inter-firm institu- } \\
\text { tions (EMEs } \\
\text { +MMEs) }\end{array}$ & $\begin{array}{l}-4.09 \\
(5.29)\end{array}$ & $\begin{array}{l}-0.07 * * \\
(0.03)\end{array}$ & $\begin{array}{l}0.05 \\
(0.04)\end{array}$ & $\begin{array}{l}0.01 \\
(0.06)\end{array}$ & $\begin{array}{l}-0.01 \\
(0.03)\end{array}$ & $\begin{array}{l}-0.04 * * \\
(0.02)\end{array}$ & $\begin{array}{l}-0.01 \\
(0.02)\end{array}$ & $\begin{array}{l}-0.37 \\
(4.10)\end{array}$ \\
\hline $\ln$ GDP & $\begin{array}{l}12.36 \\
(10.31)\end{array}$ & $\begin{array}{l}-0.04 \\
(0.05)\end{array}$ & $\begin{array}{l}0.00 \\
(0.07)\end{array}$ & $\begin{array}{l}0.02 \\
(0.06)\end{array}$ & $\begin{array}{l}-0.05 \\
(0.06)\end{array}$ & $\begin{array}{l}-0.03^{*} \\
(0.02)\end{array}$ & $\begin{array}{l}0.00 \\
(0.02)\end{array}$ & $\begin{array}{l}-1.93 \\
(7.16)\end{array}$ \\
\hline $\begin{array}{l}\text { Share of the Labour } \\
\text { force }\end{array}$ & $\begin{array}{l}0.91 * * \\
(0.37)\end{array}$ & $\begin{array}{l}0.00 \\
(0.00)\end{array}$ & $\begin{array}{l}0.00 \\
(0.00)\end{array}$ & $\begin{array}{l}-0.00 \\
(0.00)\end{array}$ & $\begin{array}{l}0.00 * * \\
(0.00)\end{array}$ & $\begin{array}{l}-0.00 \\
(0.00)\end{array}$ & $\begin{array}{l}0.00 \\
(0.00)\end{array}$ & $\begin{array}{l}-0.11 \\
(0.30)\end{array}$ \\
\hline Constant & $\begin{array}{l}-156.85^{*} \\
(101.71)\end{array}$ & $\begin{array}{l}0.42 \\
(0.53)\end{array}$ & $\begin{array}{l}0.22 \\
(0.72)\end{array}$ & $\begin{array}{l}0.47 \\
(0.71)\end{array}$ & $\begin{array}{l}0.29 \\
(0.67)\end{array}$ & $\begin{array}{l}0.37 * * \\
(0.20)\end{array}$ & $\begin{array}{l}-0.10 \\
(0.23)\end{array}$ & $\begin{array}{l}51.66 \\
(63.09)\end{array}$ \\
\hline Observations & 190 & 185 & 185 & 185 & 117 & 108 & 104 & 190 \\
\hline R-squared & 0.460 & 0.343 & 0.112 & 0.042 & 0.084 & 0.127 & 0.180 & 0.050 \\
\hline
\end{tabular}


entrepreneurs in the scientific education group appear to create more medium-low-tech ventures and fewer low-tech ventures than their counterparts in countries with vocational education systems. In terms of sector growth (models 5-7), a vocational education system seems to facilitate more growth in medium-low tech and low-tech manufacturing than a scientific education system, but these differences are only weakly significant. Finally, entrepreneurs in countries with vocational education systems appear to have lower high-growth aspirations compared to the reference category (model 8), but these differences are weakly significant, and there are no significant differences relative to entrepreneurs in the basic education systems. Overall, these results confirm Hypothesis 3, i.e. that the more education and training-related institutions facilitate the development of scientific knowledge, the more Schumpeterian are the types of entrepreneurship that emerge in the respective countries.

In Table 9, we consider the two inter-firmrelated institutional constellations as the main explanatory variables of interest. This time, the group of countries with reliable legal institutions (consisting of all LMEs and all CMEs) serves as the reference group. As can be seen in model 1, people who operate under such reliable institutions appear to perceive more business opportunities than their counterparts in the less reliable group. This also seems to translate into more venture creation, since entrepreneurs operating in a reliable legal framework create more high-tech ventures, and countries with such institutions also see more growth in medium-low-tech sectors than countries with less reliable legal institutions. Other than that, there are no significant differences between the two groups. Overall, these results confirm Hypothesis 4, i.e. that the more institutions governing inter-firm relations offer reliable environments for R\&D competition, the more they facilitate the development of Schumpeterian entrepreneurship.

As a final observation, we should point out that the regression results with respect to each separate dimension (Tables 6, 7, 8, and 9) are weaker than the results for the final country clusters (Table 5). In our view, the fact that results are stronger at this aggregate level lends strong support to Hypothesis 5: finance-related, labour-market, educational, and interfirm institutions together facilitate different types of entrepreneurship more strongly than each institution does separately.

\section{Conclusions}

To conclude, what have we learned about the institutional foundations of entrepreneurship? To begin with the institutional foundations, we saw that countries fall into distinct families with regard to finance-related, labour-market, education and training, as well as inter-firm institutions governing entrepreneurship. Interestingly, these institutional families resemble the institutional families identified in the Varieties-of-Capitalism literature rather strongly. This is noteworthy to the extent that the institutions we studied go way beyond the 'classical' institutions studied in the VoC literature, because they influence the ease (or difficulty) with which entrepreneurial ventures can acquire different types of finance, labour, and know-how. This, in turn, makes it surprising that the country groups we identify are basically identical to the ones in the VoC literature.

It is furthermore noteworthy that 'entrepreneurship-relevant' institutions also seem to form complementarities. Accordingly, we identified different varieties of entrepreneurial capitalism that are best described as LMEs, CMEs, MMEs, and EMEs. LMEs include the Anglo-Saxon economies (Ireland, the UK, and the US) with permissive financial and deregulated labour markets, scientific education systems teaching workforces general skills, and reliable legal systems governing inter-firm collaborations. In contrast, CMEs (including the Continental and Northern European economies) are characterised by somewhat permissive financial and well-regulated labour markets, vocational education systems that teach specific skills to workforces, and reliable legal systems supporting inter-firm collaborations. MMEs (including France, Italy, Portugal, and Spain), in turn, are characterised by somewhat constraining financial institutions and constraining labour markets, education systems that mostly teach basic skills to workforces, and unreliable legal systems that make interfirm collaborations difficult. Finally, EMEs are characterised by constraining financial and wellregulated labour markets, education systems that mostly teach basic skills, and unreliable legal systems that hamper inter-firm collaborations. 
It is furthermore interesting to note that these institutional constellations support different types of entrepreneurship. While entrepreneurs in CMEs outrank their counterparts in all other economies in the extent to which they perceive business opportunities, this optimism does not fully translate into the creation of Schumpeterian entrepreneurial ventures: On the one hand, entrepreneurs in CMEs create more high-tech ventures than entrepreneurs in EMEs and MMEs, but on the other, they also create more low-tech ventures than their counterparts in LMEs, whereby these ventures are characterised by limited growth overall. Contrary to that, entrepreneurs in LMEs are less optimistic than entrepreneurs in CMEs about possible business opportunities, but outperform their counterparts in other economies when it comes to actually founding Schumpeterian high-tech and medium-low-tech ventures, which also grow quite substantially. In contrast, entrepreneurs in EMEs are not overly optimistic about possible business opportunities. Furthermore, they are outperformed by entrepreneurs in both LMEs and CMEs in setting up high-tech ventures. However, EME entrepreneurs are decisively better in setting up medium-low-tech ventures than their counterparts in CMEs and MMEs alike. Importantly, though, the ventures established show little sign of substantial growth. Finally, Schumpeterian entrepreneurial activity is least developed in MMEs: This is true for both possible business opportunities as well as the start of Schumpeterian ventures. Accordingly, MME entrepreneurs are decisively more pessimistic about possible business opportunities and hardly set up any high-tech or medium-high-tech ventures compared to their counterparts in all other economies. At the same time, entrepreneurs in MMEs outperform entrepreneurs in all other economies in the extent to which they set up low-tech ventures, whereby these ventures basically do not grow substantially.

What implications do our findings have for policymakers? In a nutshell, we show that distinct institutional constellations facilitate the emergence of distinct forms of entrepreneurship. Importantly, this means that policymakers need to be aware of the implications that regulatory changes in the institutional environment will have. To be clear, the institutional environment that is most conducive to Schumpeterian forms of entrepreneurship is a deregulated financial and labour market, making rapid investments and disinvestments both easy and financially attractive, while limiting the protection of dependent employment. The Anglo-Saxon economies in general, and the US in particular, provide the most clear-cut examples. To facilitate more Schumpeterian - that is, radically innovative, highgrowth-entrepreneurship in Continental, Southern and Eastern Europe, policy-makers would thus need to deregulate both labour and financial markets. Given the complementarity of the different institutions underpinning labour and financial markets, a partial flexibilisation would - in our view - hardly be successful! The case of the Dutch economy provides a particularly telling example, as the tax breaks introduced about a decade ago led to a steep increase in solo selfemployment without having the desired effect of facilitating high-growth entrepreneurship (Liebregts 2016).

But is the full-fledged deregulation of labour and financial markets actually desirable? In our view, this is not necessarily the case. While the protection of dependent employment has a negative impact on the development of radically innovative, high-growth entrepreneurship, it stimulates the development of incrementally innovative, slow-growth entrepreneurship, as exemplified by numerous Continental European countries. Only when employment protection becomes stifling for the employing firms, so that vacancies are no longer created because it is impossible to dismiss employees in case of economically harmful behaviour (as this is the case in most Mediterranean economies), then labour market reforms are opportune. But even in these instances, constraining labour and financial market institutions leads to entrepreneurial specialisation, namely the development of low-tech, no-growth ventures. In more general terms, any form of financial and labourmarket constellation in Europe facilitates the development of distinct entrepreneurial forms. In other words, an institutional constellation that is equally conducive to radically innovative, high-tech, high-growth; as well as to incrementally innovative, medium-tech, low-growth; as well as to imitative, low-tech, no-growth entrepreneurship does not exist and cannot be created! Policymakers will always be faced with trade-offs.

Furthermore, one should keep in mind that the regulation of labour and financial markets and thus, their deregulation, not only serves the purpose of stimulating distinct forms of entrepreneurship. They have broader societal aims, so that the deregulation of labour and financial markets also has effects that may be societally undesirable. To give just some examples: Strong wage inequalities and increasing disparities between the rich 
and the poor, as well as systematic underinsurance against the risks of disability, old-age poverty, and illness are also typical characteristics of deregulated labour markets. Similarly, high capital market volatility and risky investments go hand in hand with deregulated financial markets. In short, a 'perfect' institutional constellation that stimulates Schumpeterian entrepreneurship while facilitating social cohesion does not exist and cannot be created either!

Furthermore, policy-makers may wonder whether the stimulation of radical-innovation, high-growth entrepreneurship is actually necessary. In the entrepreneurship literature, Schumpeterian ventures are often described as superior because they are more conducive to growth and thus, to the creation of employment. This idea is supported by our analyses, as we find that the innovation-oriented entrepreneurs in LMEs display higher growth ambitions than entrepreneurs in the other countries studied. Importantly, though, radically innovative entrepreneurship is also more volatile. As indicated by our analyses, radically innovative ventures not only grow more strongly, they also fail more frequently: Accordingly, we did not find more sustainable venture creation rates in LMEs than in other economies as soon as corporate failure (or exit) rates were considered together with venture creation (or entry) rates. Hence, Schumpeterian entrepreneurship does not necessarily mean employment and growth that is sustainable. On the contrary, incrementally innovative, medium-tech and imitative, low-tech entrepreneurship are more stable and thus, more reliable and may, in the long run, therefore be equally viable 'engines of economic development'. In sum, the stimulation of - and specialisation in - the same type of radically innovative, high-tech, high-growth entrepreneurship across the developed Western economies seems to be neither desirable nor necessary.

Does this mean that policy-makers cannot, or do not need to, proceed to any institutional reform? In our view, this is not the case either. For starters, our analysis clearly demonstrates the importance of reliable legal systems that facilitate inter-firm collaborations. These are the fundamental rules of the game, and we conclude that all member states must ensure that these rules are stable and secure. As for the rules governing labour and financial markets, although flexibilisation is likely desirable here as well, things are more equivocal: Clearly, there are different trajectories that countries can take in this respect, but they should be taken with awareness of the extant complementarities between the different sets of institutions. For instance, Denmark's flexicurity model, which combines generous welfare systems with weak job security mandates (Andersen and Svarer 2007), can provide an example for other CMEs. In Ireland's progress in entrepreneurial activity, access to loan finance and credit facilities from banks has been identified as a constraint for entrepreneurial activity. Our findings here would suggest that following a similar strategy in terms of financial institutions to the ones in the United States and the United Kingdom would be more useful than introducing reforms where banks or government provide funds, which is a strategy followed in countries such as Denmark that have a social democrat model. In conclusion, our findings in this paper highlight the necessity of identifying entrepreneurship policies that correspond to the diversity in the institutional structure in Europe.

That said, we call for some caution not to draw overly general conclusions from our research since it is not without limitations. First, it only provides a snapshot of institutions over a limited time period, and therefore hardly illustrates all possible changes occurring in institutional structures. Yet institutional evolution has been far from unidirectional, and institutional reversals are common throughout history (Acemoglu and Robinson 2012). A historical study of the evolution of institutional diversity therefore constitutes a first important avenue for future research. Second, variation exists within countries at the level of states, regions, and individuals. To better understand the complex relations between institutions and individual behavior, a multilevel analysis would be desirable, examining how institutions influence individual entrepreneurial behavior not only at the country level, but also at the level of states or regions. A further investigation of these issues constitutes a second avenue for future research.

Acknowledgments This work is part of the European Commission 2020 Horizon project 'Financial and Institutional Reforms to build an Entrepreneurial Society (FIRES) in Europe'. We are grateful for useful comments and suggestions from Gerarda Westerhuis, Magnus Henrekson and Mikael Stenkula. Financial support from the Jan Wallander and Tom Hedelius Research Foundation is gratefully acknowledged. This project has also received funding from the European Union's Horizon 2020 research and innovation programme under grant agreement No 649378. This paper reflects only the author's view and the Agency is not responsible for any use that may be made of the information it contains. 


\section{Appendix}

Table 10 VoC framework. Regressions with the identified clusters as core explanatory variables. CMEs serve as base case

\begin{tabular}{|c|c|c|c|c|c|c|c|c|}
\hline & $\begin{array}{l}\text { (1) } \\
\text { Perceived } \\
\text { Opportunity }\end{array}$ & $\begin{array}{l}\text { (2) } \\
\text { Births in high-tech } \\
\text { and medium-high- } \\
\text { tech sectors }\end{array}$ & $\begin{array}{l}\text { (3) } \\
\text { Births in } \\
\text { medium-low- } \\
\text { tech sectors }\end{array}$ & $\begin{array}{l}\text { (4) } \\
\text { Births in } \\
\text { low-tech } \\
\text { sectors }\end{array}$ & $\begin{array}{l}\text { (5) } \\
\text { Growth in } \\
\text { high-tech } \\
\text { sectors }\end{array}$ & $\begin{array}{l}\text { (6) } \\
\text { Growth in } \\
\text { medium-low- } \\
\text { tech sectors }\end{array}$ & $\begin{array}{l}\text { (7) } \\
\text { Growth in } \\
\text { low-tech } \\
\text { sectors }\end{array}$ & $\begin{array}{l}(8) \\
\text { High- } \\
\text { growth } \\
\text { aspirations }\end{array}$ \\
\hline LMEs & $\begin{array}{c}-6.11 * * \\
(3.06)\end{array}$ & $\begin{array}{c}0.01 \\
(0.03)\end{array}$ & $\begin{array}{c}0.04 \\
(0.04)\end{array}$ & $\begin{array}{c}-0.06 * * * \\
(0.02)\end{array}$ & $\begin{array}{l}-0.01 \\
(0.02)\end{array}$ & $\begin{array}{l}-0.00 \\
(0.01)\end{array}$ & $\begin{array}{c}-0.02 * \\
(0.01)\end{array}$ & $\begin{array}{c}9.52 * * * \\
(2.53)\end{array}$ \\
\hline EMEs & $\begin{array}{l}-3.69 \\
(6.43)\end{array}$ & $\begin{array}{c}-0.06^{* *} \\
(0.03)\end{array}$ & $\begin{array}{l}0.09 * * \\
(0.04)\end{array}$ & $\begin{array}{r}-0.03 \\
(0.03)\end{array}$ & $\begin{array}{l}-0.01 \\
(0.03)\end{array}$ & $\begin{array}{c}0.00 \\
(0.02)\end{array}$ & $\begin{array}{c}0.02 \\
(0.02)\end{array}$ & $\begin{array}{l}7.87 * * \\
(4.07)\end{array}$ \\
\hline MMEs & $\begin{array}{c}-10.92 * * \\
(4.74)\end{array}$ & $\begin{array}{c}-0.10^{* * * *} \\
(0.02)\end{array}$ & $\begin{array}{l}-0.05 \\
(0.05)\end{array}$ & $\begin{array}{c}0.14 * * * \\
(0.05)\end{array}$ & $\begin{array}{c}-0.05^{*} \\
(0.03)\end{array}$ & $\begin{array}{l}-0.03 \\
(0.03)\end{array}$ & $\begin{array}{l}-0.01 \\
(0.02)\end{array}$ & $\begin{array}{l}-0.60 \\
(2.52)\end{array}$ \\
\hline $\ln$ GDP & $\begin{array}{l}13.22 * \\
(8.05)\end{array}$ & $\begin{array}{l}-0.04 \\
(0.04)\end{array}$ & $\begin{array}{l}-0.02 \\
(0.06)\end{array}$ & $\begin{array}{c}0.05 \\
(0.04)\end{array}$ & $\begin{array}{l}-0.07 \\
(0.05)\end{array}$ & $\begin{array}{c}0.00 \\
(0.04)\end{array}$ & $\begin{array}{c}0.03 \\
(0.03)\end{array}$ & $\begin{array}{l}-1.38 \\
(6.39)\end{array}$ \\
\hline $\begin{array}{l}\text { Share of the } \\
\text { Labor } \\
\text { force }\end{array}$ & $(0.35)$ & $(0.00)$ & $(0.00)$ & $-0.01 * * *$ & $(0.00)$ & $(0.00)$ & $(0.00)$ & $(0.23)$ \\
\hline Constant & $\begin{array}{c}-160.88^{* *} \\
(90.59)\end{array}$ & $\begin{array}{c}0.45 \\
(0.46)\end{array}$ & $\begin{array}{c}0.22 \\
(0.61)\end{array}$ & $\begin{array}{c}0.40 \\
(0.37)\end{array}$ & $\begin{array}{c}0.42 \\
(0.70)\end{array}$ & $\begin{array}{l}-0.09 \\
(0.32)\end{array}$ & $\begin{array}{c}-0.45^{*} \\
(0.29)\end{array}$ & $\begin{array}{c}16.54 \\
(59.31)\end{array}$ \\
\hline Observations & 190 & 185 & 185 & 185 & 117 & 108 & 104 & 190 \\
\hline $\begin{array}{l}\text { Adjusted } \\
\text { R-squared }\end{array}$ & 0.476 & 0.494 & 0.326 & 0.544 & 0.050 & 0.014 & 0.139 & 0.243 \\
\hline
\end{tabular}

Table 11 VoC framework. Regressions with the identified clusters as core explanatory variables. MMEs serve as base case

\begin{tabular}{|c|c|c|c|c|c|c|c|c|}
\hline & $\begin{array}{l}\text { (1) } \\
\text { Perceived } \\
\text { Opportunity }\end{array}$ & $\begin{array}{l}\text { (2) } \\
\text { Births in high-tech } \\
\text { and medium-high- } \\
\text { tech sectors }\end{array}$ & $\begin{array}{l}\text { (3) } \\
\text { Births in } \\
\text { medium-low- } \\
\text { tech sectors }\end{array}$ & $\begin{array}{l}\text { (4) } \\
\text { Births in } \\
\text { low-tech } \\
\text { sectors }\end{array}$ & $\begin{array}{l}\text { Gr) } \\
\text { Growth in } \\
\text { high-tech } \\
\text { sectors }\end{array}$ & $\begin{array}{l}\text { (6) } \\
\text { Growth in } \\
\text { medium-low- } \\
\text { tech sectors }\end{array}$ & $\begin{array}{l}\text { Gr) } \\
\text { Growth in } \\
\text { low-tech } \\
\text { sectors }\end{array}$ & $\begin{array}{l}(8) \\
\text { High- } \\
\text { growth } \\
\text { aspirations }\end{array}$ \\
\hline LMEs & $\begin{array}{l}4.81 * * \\
(2.76)\end{array}$ & $\begin{array}{c}0.11 * * * \\
(0.03)\end{array}$ & $\begin{array}{l}0.08 * \\
(0.05)\end{array}$ & $\begin{array}{c}-0.20 * * * \\
(0.05)\end{array}$ & $\begin{array}{l}0.04 * \\
(0.02)\end{array}$ & $\begin{array}{c}0.02 \\
(0.03)\end{array}$ & $\begin{array}{l}-0.01 \\
(0.02)\end{array}$ & $\begin{array}{c}10.12 * * * \\
(3.54)\end{array}$ \\
\hline CMEs & $\begin{array}{c}10.92 * * \\
(4.74)\end{array}$ & $\begin{array}{c}0.10 * * * \\
(0.02)\end{array}$ & $\begin{array}{c}0.05 \\
(0.05)\end{array}$ & $\begin{array}{c}-0.14 * * * \\
(0.05)\end{array}$ & $\begin{array}{l}0.05 * \\
(0.03)\end{array}$ & $\begin{array}{c}0.03 \\
(0.03)\end{array}$ & $\begin{array}{c}0.01 \\
(0.02)\end{array}$ & $\begin{array}{c}0.60 \\
(2.52)\end{array}$ \\
\hline EMEs & $\begin{array}{l}7.23 * * \\
(3.03)\end{array}$ & $\begin{array}{c}0.03 * * * \\
(0.01)\end{array}$ & $\begin{array}{c}0.14 * * * \\
(0.04)\end{array}$ & $\begin{array}{c}-0.16^{* * * *} \\
(0.04)\end{array}$ & $\begin{array}{c}0.03 * * * \\
(0.01)\end{array}$ & $\begin{array}{c}0.03 \\
(0.02)\end{array}$ & $\begin{array}{l}0.03 * \\
(0.02)\end{array}$ & $\begin{array}{c}8.47 * * * \\
(2.77)\end{array}$ \\
\hline $\ln$ GDP & $\begin{array}{l}13.22 * \\
(8.05)\end{array}$ & $\begin{array}{l}-0.04 \\
(0.04)\end{array}$ & $\begin{array}{l}-0.02 \\
(0.06)\end{array}$ & $\begin{array}{c}0.05 \\
(0.04)\end{array}$ & $\begin{array}{l}-0.07 \\
(0.05)\end{array}$ & $\begin{array}{c}0.00 \\
(0.04)\end{array}$ & $\begin{array}{c}0.03 \\
(0.03)\end{array}$ & $\begin{array}{l}-1.38 \\
(6.39)\end{array}$ \\
\hline $\begin{array}{l}\text { Share of the } \\
\text { Labour } \\
\text { force }\end{array}$ & $0.88^{* *} *$ & $(0.00)$ & $0.00 *$ & $-0.01 * * *$ & $0.00 *$ & $(0.00)$ & $(0.00)$ & $(0.23)$ \\
\hline Constant & $\begin{array}{c}-171.79 * * \\
(86.89)\end{array}$ & $\begin{array}{c}0.35 \\
(0.44)\end{array}$ & $\begin{array}{c}0.17 \\
(0.59)\end{array}$ & $\begin{array}{l}0.54 * \\
(0.36)\end{array}$ & $\begin{array}{c}0.37 \\
(0.67)\end{array}$ & $\begin{array}{l}-0.11 \\
(0.30)\end{array}$ & $\begin{array}{c}-0.46^{*} \\
(0.27)\end{array}$ & $\begin{array}{c}15.94 \\
(57.39)\end{array}$ \\
\hline Observations & 190 & 185 & 185 & 185 & 117 & 108 & 104 & 190 \\
\hline R-squared & 0.476 & 0.494 & 0.326 & 0.544 & 0.050 & 0.014 & 0.139 & 0.243 \\
\hline
\end{tabular}


Table 12 VoC framework. Regressions with the identified clusters as core explanatory variables. EMEs serve as base case

\begin{tabular}{|c|c|c|c|c|c|c|c|c|}
\hline & $\begin{array}{l}\text { (1) } \\
\text { Perceived } \\
\text { Opportunity }\end{array}$ & $\begin{array}{l}\text { Births in high-tech } \\
\text { and medium-high- } \\
\text { tech sectors }\end{array}$ & $\begin{array}{l}\text { (3) } \\
\text { Births in } \\
\text { medium-low- } \\
\text { tech sectors }\end{array}$ & $\begin{array}{l}\text { (4) } \\
\text { Births in } \\
\text { low-tech } \\
\text { sectors }\end{array}$ & $\begin{array}{l}\text { Growth in } \\
\text { high-tech } \\
\text { sectors }\end{array}$ & $\begin{array}{l}\text { (6) } \\
\text { Growth in } \\
\text { medium-low- } \\
\text { tech sectors }\end{array}$ & $\begin{array}{l}\text { G) } \\
\text { Growth in } \\
\text { low-tech } \\
\text { sectors }\end{array}$ & $\begin{array}{l}(8) \\
\text { High- } \\
\text { growth } \\
\text { aspirations }\end{array}$ \\
\hline LMEs & $\begin{array}{l}-2.42 \\
(4.75)\end{array}$ & $\begin{array}{l}0.08^{* * *} \\
(0.03)\end{array}$ & $\begin{array}{l}-0.06 \\
(0.05)\end{array}$ & $\begin{array}{l}-0.03 \\
(0.03)\end{array}$ & $\begin{array}{l}0.01 \\
(0.02)\end{array}$ & $\begin{array}{l}-0.00 \\
(0.02)\end{array}$ & $\begin{array}{l}-0.04 * * \\
(0.02)\end{array}$ & $\begin{array}{l}1.64 \\
(4.88)\end{array}$ \\
\hline CMEs & $\begin{array}{l}3.69 \\
(6.43)\end{array}$ & $\begin{array}{l}0.06^{* *} \\
(0.03)\end{array}$ & $\begin{array}{l}-0.09^{* *} \\
(0.04)\end{array}$ & $\begin{array}{l}0.03 \\
(0.03)\end{array}$ & $\begin{array}{l}0.01 \\
(0.03)\end{array}$ & $\begin{array}{l}-0.00 \\
(0.02)\end{array}$ & $\begin{array}{l}-0.02 \\
(0.02)\end{array}$ & $\begin{array}{l}-7.87 * * \\
(4.07)\end{array}$ \\
\hline MMEs & $\begin{array}{l}-7.23 * * \\
(3.03)\end{array}$ & $\begin{array}{l}-0.03^{* * * *} \\
(0.01)\end{array}$ & $\begin{array}{l}-0.14 * * * \\
(0.04)\end{array}$ & $\begin{array}{l}0.16^{* * * *} \\
(0.04)\end{array}$ & $\begin{array}{l}-0.03 * * * \\
(0.01)\end{array}$ & $\begin{array}{l}-0.03 \\
(0.02)\end{array}$ & $\begin{array}{l}-0.03 * \\
(0.02)\end{array}$ & $\begin{array}{l}-8.47 * * * \\
(2.77)\end{array}$ \\
\hline $\ln$ GDP & $\begin{array}{l}13.22 * \\
(8.05)\end{array}$ & $\begin{array}{l}-0.04 \\
(0.04)\end{array}$ & $\begin{array}{l}-0.02 \\
(0.06)\end{array}$ & $\begin{array}{l}0.05 \\
(0.04)\end{array}$ & $\begin{array}{l}-0.07 \\
(0.05)\end{array}$ & $\begin{array}{l}0.00 \\
(0.04)\end{array}$ & $\begin{array}{l}0.03 \\
(0.03)\end{array}$ & $\begin{array}{l}-1.38 \\
(6.39)\end{array}$ \\
\hline $\begin{array}{l}\text { Share of the } \\
\text { Labour } \\
\text { force }\end{array}$ & $0.88 * *$ & $(0.00)$ & $0.00 *$ & $-0.01 * * *$ & $0.00 *$ & $(0.00)$ & $(0.00)$ & $(0.23)$ \\
\hline Constant & $\begin{array}{l}-164.57 * * \\
(85.05)\end{array}$ & $\begin{array}{l}0.39 \\
(0.43)\end{array}$ & $\begin{array}{l}0.31 \\
(0.59)\end{array}$ & $\begin{array}{l}0.37 \\
(0.36)\end{array}$ & $\begin{array}{l}0.40 \\
(0.67)\end{array}$ & $\begin{array}{l}-0.09 \\
(0.30)\end{array}$ & $\begin{array}{l}-0.43^{*} \\
(0.27)\end{array}$ & $\begin{array}{l}24.42 \\
(55.83)\end{array}$ \\
\hline Observations & 190 & 185 & 185 & 185 & 117 & 108 & 104 & 190 \\
\hline R-squared & 0.476 & 0.494 & 0.326 & 0.544 & 0.050 & 0.014 & 0.139 & 0.243 \\
\hline
\end{tabular}

Open Access This article is distributed under the terms of the Creative Commons Attribution 4.0 International License (http:// creativecommons.org/licenses/by/4.0/), which permits unrestricted use, distribution, and reproduction in any medium, provided you give appropriate credit to the original author(s) and the source, provide a link to the Creative Commons license, and indicate if changes were made.

\section{References}

Acemoglu, D., \& Robinson, J. A. (2012). Why nations fail: the origins of power, prosperity, and poverty. New York: Crown Publishers.

Acs, Z. J. (2008). Foundations of high impact entrepreneurship. Foundations and Trends in Entrepreneurship, 4(6), 535-620. https://doi.org/10.1561/0300000025.

Acs, Z. J., Desai, S., \& Hessels, J. (2008). Entrepreneurship, economic development, and institutions. Small Business Economics, 31(3), 219-234. https://doi.org/10.1007 /s11187-008-9135-9.

Altindag, E., Zehir, C., \& Zafer, A. A. (2011). Strategic orientations and their effects on firm performance in turkish family owned firms. Eurasian Business Review, 1(1), 18-36. https://doi.org/10.14208/BF03353796.

Amable, B. (2003). The diversity of modern capitalism. Oxford: Oxford University Press.

Andersen, T. M., \& Svarer, M. (2007). Flexicurity-labour market performance in Denmark. CESifo Economic Studies, 53(3), 389-429. https://doi.org/10.1093/cesifo/ifm015.
Autio, E., \& Acs, Z. J. (2010). Intellectual property protection and the formation of entrepreneurial growth aspirations. Strategic Entrepreneurship Journal, 4(4), 234-251.

Bartelsman, E., Scarpetta, S., \& Schivardi, F. (2005). Comparative Analysis of Firm Demographics and Survival: Evidence from Micro-level Sources in OECD Countries. Industrial and Corporate Change, 14(3), 365-391.

Baumol, W. (1990). Entrepreneurship: productive, unproductive, and destructive. Journal of Political Economy, 98(5), 893921. https://doi.org/10.1016/0883-9026(94)00014-X.

Bjørnskov, C., \& Foss, N. J. (2013). How strategic entrepreneurship and the institutional context drive economic growth. Strategic Entrepreneurship Journal, 7(1), 50-69.

Bottazzi, L., \& Da Rin, M. (2002). Venture capital in Europe and the financing of innovative companies. Economic Policy, 17(34), 229-269.

Calcagno, P. T., \& Sobel, R. S. (2014). Regulatory costs on entrepreneurship and establishment employment size. Small Business Economics, 42(3), 541-559. https://doi. org/10.1007/s11187-013-9493-9.

Case, S., \& Harris, D. (2012). The startup uprising: Eighteen months of the startup America Parternship. Ewing Marion Kauffman Foundation, 1-49.

Coad, A. (2009). The growth of firms: A survey of theories and empirical evidence. Cheltenham: Edward Elgar Publishing.

Coad, A., \& Rao, R. (2008). Innovation and firm growth in hightech sectors: a quantile regression approach. Research Policy, 37(4), 633-648. https://doi.org/10.1016/j.respol.2008.01.003.

Colombo, M. G., \& Grilli, L. (2005). Founders' human capital and the growth of new technology based firms: a competencebased view. Research Policy, 34, 795-816. 
Corsino, M., \& Gabriele, R. (2011). Product innovation and firm growth: evidence from the integrated circuit industry. Industrial and Corporate Change, 20(1), 29-56. https://doi. org/10.1093/icc/dtq050.

Da Rin, M., Nicodano, G., \& Sembenelli, A. (2006). Public policy and the creation of active venture capital markets. Journal of Public Economics, 90(8-9), 1699-1723. https://doi. org/10.1016/j.jpubeco.2005.09.013.

Delmar, F., \& Wennberg, K. (2010). Knowledge Intensive Entrepreneurship: The Birth, Growth and Demise of Entrepreneurial Firms. Edward Elgar Publishing.

Eurostat (2008). NACE Rev. 2. Statistical classification of economic activities in the European Community. http://ec. europa.eu/eurostat/documents/3859598/5902521/KSRA-07-015-EN.PDF.

Fenn, G., Liang, N., \& Prowse, S. (1995). The economics of the private equity market. Washington, D.C.: Board of Governors of the Federal Reserve System.

Freel, M. S. (2000). Do small innovating firms outperform noninnovators? Small Business Economics, 14(3), 195-210. https://doi.org/10.1023/A:1008100206266.

Geroski, P. A. (1995). What Do We Know about Entry? International Journal of Industrial Organization, 13(4), 421-40.

Golpe, A., Millán, J., \& Román, C. (2008). Labor market institutions and entrepreneurship. In E. Congregado (Ed.), Measuring entrepreneurship (pp. 279-296). Springer US: International Studies in Entrepreneurship.

Gompers, P. A., \& Lerner, J. (1999). An analysis of compensation in the U.S. venture capital partnership. Journal of Financial Economics, 51(1), 3-44. https://doi.org/10.1016/S0304-405 $\mathrm{X}(98) 00042-7$.

Hall, R. E., \& Jones, C. I. (1999). Why do some countries produce so much more output per worker than others? Quarterly Journal of Economics, 114(1), 83-116. https://doi. org/10.1162/003355399555954.

Hall, P. A., \& Soskice, D. W. (2001). An introduction to varieties of capitalism. In P. A. Hall \& D. W. Soskice (Eds.), Varieties of capitalism - the institutional foundations of comparative advantage (pp. 1-68). Oxford: Oxford University Press.

Hancké, B., Rhodes, M., \& Thatcher, M. (2007). Beyond varieties of capitalism. Oxford: Oxford University Press.

Hechavarria, D. M., \& Reynolds, P. D. (2009). Cultural norms \& business start-ups: the impact of national values on opportunity and necessity entrepreneurs. International Entrepreneurship and Management Journal, 5(4), 417-437. https://doi. org/10.1007/s11365-009-0115-6.

Henrekson, M., \& Johansson, D. (2009). Competencies and institutions fostering high-growth firms. Foundations and Trends in Entrepreneurship, 5(1), 1-80. https://doi. org/10.1561/0300000026.

Henrekson, M., \& Rosenberg, N. (2001). Designing efficient institutions for science-based entrepreneurship: lessons from the U.S. and Sweden. Journal of Technology Transfer, 26(2), 207-231. https://doi.org/10.1023/A:1011153922906.

Henrekson, M., \& Sanadaji, T. (2014). Small business activity does not measure entrepreneurship. PNAS, 111(5), 17601765. https://doi.org/10.1073/pnas.1307204111.

Henrekson, M., \& Stenkula, M. (2016). Understanding entrepreneurship: definition, function and policy. Lund: Studentlitteratur.
Herrmann, A. M. (2008). One political economy, one competitive strategy? Comparing pharmaceutical firms in Germany, Italy, and the UK. Oxford: Oxford University Press.

Herrmann, A. M., \& Peine, A. (2011). When 'national innovation system' meet 'varieties of capitalism' arguments on labour qualifications: On the skill types and scientific knowledge needed for radical and incremental product innovations. Research Policy, 40(5), 687-701. https://doi.org/10.1016/j. respol.2011.02.004.

Hessels, J., Van Stel, A. J., Brouwer, P., \& Wennekers, S. (2007). Social security arrangements and early-stage entrepreneurial activity. Comparative Labor Law \& Policy Journal, 28(4) http://papers.ssrn.com/sol3/papers.cfm?abstract_ id $=1006256$.

Jackson, G., \& Deeg, R. (2012). The Long-Term Trajectories of Institutional Change in European Capitalism. Journal of European Public Policy, 19(8), 1109-1125.

Kaiser, H. F. (1960). The application of electronic computers to factor analysis. Educational and Psychological Measurement, 20(1), 141-151. https://doi.org/10.1177 /001316446002000116.

Keuschnigg, C., \& Nielsen, S. B. (2004). Taxation and venture capital backed entrepreneurship. International Tax and Public Finance, 11(4), 369-390. https://doi. org/10.1023/B:ITAX.0000033984.29301.9e.

Klein, B. (1996). Why hold-ups occur: the self-enforcing range of contractual relationships. Economic Inquiry, 34(3), 444-463.

Liebregts, W. (2016). Institutional explanations for patterns of entrepreneurial activity: The case of the Dutch task market. FIRES Working Paper. http://www.projectfires.eu/wpcontent/uploads/2016/06/D5.3-Case-Study-on-Dutch-SoloSelf-Employment.pdf.

Lundvall, B. A. (1992). User-producer relationships, national systems of innovation and internationalisation. In B. A. Lundvall (Ed.), National systems of innovation - towards a theory of innovation and interactive learning (pp. 45-67). London: Pinter Publishers.

Milgrom, P., \& Roberts, J. (1992). Economics, organization and management. Englewood Cliffs: Prentice Hall.

Misher, N. (1984). Tax consequences of exercising an incentive stock option with stock of the granting corporation. Tax Executive, 36, 357-363.

Molina, O., \& Rhodes, M. (2007). The political economy of adjustment in mixed market economies: A study of Spain and Italy. In B. Hancké, M. Rhodes, \& M. Tatcher (Eds.), Beyond varieties of capitalism: conflict, contradictions and complementarities in the European economy (pp. 223-252). Oxford: Oxford University Press.

Murphy, K. M., Shleifer, A., \& Vishny, R. W. (1990). The allocation of talent: implications for growth. Quarterly Journal of Economics, 106(2), 503-530. https://doi. org/10.2307/2937945.

Nölke, A., \& Vliegenthart, A. (2009). Enlarging the varieties of capitalism: the emergence of dependent market economies in east Central Europe. World Politics, 61(4), 670-702. https://doi.org/10.1017/S0043887109990098.

North, D. C. (1990). Institutions, institutional change, and economic performance. Cambridge: Cambridge University Press.

OECD (2003). OECD Science, Technology and Industry Scoreboard 2003. OECD Publishing. 
Pfeffer, J., \& Salancik, G. R. (1978). The external control of organizations: a resource dependence perspective. New York: Harper \& Row.

Rogerson, W. P. (1992). Contractual solutions to the hold-up problem. Review of Economic Studies, 59(4), 777-794. https://doi.org/10.2307/2297997.

Román, C., Congregado, E., \& Millán, J. M. (2011). “The role of labor market institutions on entrepreneurship dynamics in times of crisis: evidence from European countries." In G.D. Libecap, \& S. Hoskinson (Eds.), Entrepreneurship and Global Competitiveness in Regional Economies: Determinants and Policy Implications (pp. 161-183). Advances in the Study of Entrepreneurship, Innovation \& Economic Growth. Bingley: Howard House, Emerald Group Publishing Limited.

Schneider, M. R., \& Paunescu, M. (2012). Changing varieties of capitalism and revealed comparative advantages from 1990 to 2005: a test of the hall and Soskice claims. Socio-Economic Review, 10(4), 731-753. https://doi. org/10.1093/ser/mwr038.

Sobel, R. S. (2008). Testing Baumol: Institutional quality and the productivity of entrepreneurship. Journal of Business Venturing, 23(6), 641-655. https://doi.org/10.1016/j. jbusvent.2008.01.004.

Stam, E. (2014). The Dutch entrepreneurial ecosystem. SSRN Electronic Journal. https://doi.org/10.2139/ssrn.2473475.

Stenholm, P., Acs, Z. J., \& Wuebker, R. (2013). Exploring country-level institutional arrangements on the rate and type of entrepreneurial activity. Journal of Business Venturing, 28(1), 176-193. https://doi.org/10.1016/j. jbusvent.2011.11.002.

Streeck, W., \& Thelen, K. (2005). Introduction: Institutional change in advanced political economies. In W. Streeck \& $\mathrm{K}$. Thelen (Eds.), Beyond continuity: Institutional change in advanced political economies (pp. 1-39). Oxford: Oxford University Press.

Suhr, D. (2005). Principal component analysis vs. exploratory factor analysis. SUGI 30 Proceedings. Retrieved April 30 2017 from http://www2.sas.com/proceedings/sugi30 /Leadrs30.pdf.
Tate, J. (2001). National varieties of standardization. In P. A. Hall \& D. W. Soskice (Eds.), Varieties of capitalism - the institutional foundations of comparative advantage (pp. 442-473). Oxford: Oxford University Press.

Taylor, M. Z., \& Wilson, S. (2012). Does culture still matter? The effects of individualism on National Innovation Rates. Journal of Business Venturing, 27(2), 234-247. https://doi. org/10.1016/j.jbusvent.2010.10.001.

Teece, D. J., \& Pisano, G. (1998). The dynamic capabilities of firms. In G. Dosi, D. J. Teece, \& J. Chytry (Eds.), (pp. 193212). Oxford: Oxford University Press.

Teubner, G. (2001). Legal irritants: How unifying law ends up in new divergences. In P. A. Hall \& D. W. Soskice (Eds.), Varieties of capitalism - the institutional foundations of comparative advantage (pp. 417-441). Oxford: Oxford University Press.

Urbano, D., \& Alvarez, C. (2014). Institutional dimensions and entrepreneurial activity: an international study. Small Business Economics, 42(4), 703-716. https://doi. org/10.1007/s11187-013-9523-7.

Vitols, S. (2001). Varieties of corporate governance: comparing Germany and the UK. In P. A. Hall \& D. W. Soskice (Eds.), Varieties of capitalism - the institutional foundations of comparative advantage (pp. 337-360). Oxford: Oxford University Press.

Vivarelli, M. (2013). Is entrepreneurship necessarily good? Microeconomic evidence from developed and developing countries. Industrial and Corporate Change, 22(6), 14531495. https://doi.org/10.1093/icc/dtt005.

Vivarelli, M., \& Audretsch, D. (1998). The link between the entry decision and post-entry performance: evidence from Italy. Industrial and Corporate Change, 7(3), 485-500. https://doi.org/10.1093/icc/7.3.485.

WEF. (2013). Entrepreneurial ecosystems around the globe and company growth dynamics. World Economic Forum: Davos.

Wennekers, S., \& Thurik, A. R. (1999). Linking entrepreneurship and economic growth. Small Business Economics, 13(1), 2756. https://doi.org/10.1023/A:1008063200484.

Williamson, O. E. (1985). The economic institutions of capitalism: firms, markets, relational contracting. New York: Free Press. 